\title{
Security-voting structure and equity financing in the Banking Sector: 'One Head-One Vote' versus 'One Share-One Vote'
}

January 2019

Riccardo Ferretti ${ }^{\mathrm{a}}$, Pierpaolo Pattitoni ${ }^{\mathrm{b}}$, Alex Castelli $^{\mathrm{c}}$

\begin{abstract}
Using a unique dataset including all rights issues of new shares and other equity-like securities announced by Italian listed banks between 1989 and 2014, and exploiting the ideal setting provided by the Italian Banking Law, which allows for listed co-operative banks, we test if the 'one head-one vote' principle of co-operative banks and the 'one share-one vote' voting system of joint stock banks imply different agency costs of equity. Our empirical results, obtained using an event-study methodology, regressions and matching estimators, support our research hypothesis that co-operative banks have greater agency costs of equity compared to joint stock banks, and contribute to the literature on demutualization and cooperative hybrids.
\end{abstract}

Keywords: Agency Costs, Banks, Corporate Governance, Corporate Control, Seasoned Equity Offering

JEL classification: G21, G32

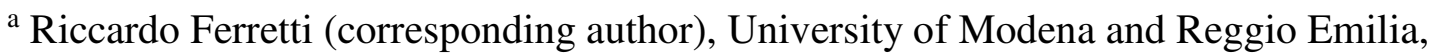
Department of Communication and Economics, and Cefin (Centro Studi Banca e Finanza), viale A. Allegri, 9, 42121 Reggio Emilia, Italy. Email: riccardo.ferretti@unimore.it.

${ }^{\mathrm{b}}$ Pierpaolo Pattitoni, University of Bologna, Department of Management, via Capo di Lucca, 34, 40126 Bologna, and Cefin (Centro Studi Banca e Finanza), viale A. Allegri, 9, 42121 Reggio Emilia, Italy. Email: pierpaolo.pattitoni@unibo.it.

${ }^{c}$ Alex Castelli, Henley Business School, University of Reading, Business Informatics, Systems and Accounting, Whiteknights, Reading, RG6 6UD, United Kingdom. Email: a.castelli@pgr.reading.ac.uk.

This research did not receive any specific grant from funding agencies in the public, commercial, or not-for-profit sectors. 


\section{Introduction}

We investigate whether the security-voting structure affects the value of equity in case of new share issues. The implications stemming from different security-voting structures have been long-debated in the literature that deals with the optimal allocation of voting rights among shareholders. The most common structure is the so-called 'one share - one vote' (1S1V) where the right to vote of each shareholder is proportional to her amount of equity capital. However, several deviations from this principle do exists: dual-class shares, stock pyramids, cross-ownership just to mention a few examples.

The theoretical literature on security-voting structure follows three main strands (Burkart and Lee, 2008): (i) the impact of non-voting shares on takeover outcomes; (ii) the effect of disproportional voting power on the incentive of blockholders; (iii) the consequences of the 1S1V rule for firms' choice of financing and ownership. The empirical literature devotes specific attention to the impact of disproportional ownership on the value of outside equity (Adams and Ferreira, 2008). Our paper explores a neglected deviation from the 1S1V principle despite its diffusion: the 'one head - one vote' (1H1V) structure characterizing cooperative firms. More specifically, we compare Joint Stock Banks (JSBs) and Co-operative Banks (CBs) on the ground of the market reaction following the offer of new shares. As far as we know, our research is the first attempt to analyse if the $1 \mathrm{H} 1 \mathrm{~V}$ principle that underpins $\mathrm{CBs}$ and other mutualistic organizations acts as an obstacle to raising new capital compared to the $1 \mathrm{~S} 1 \mathrm{~V}$ principle of JSBs.

We perform such a comparison for Italian JSBs and CBs as Italy is an ideal setting for this analysis. First, in contrast to most countries, the Italian Stock Exchange lists a relatively high number of commercial banks - both JSBs and CBs. Second, the listed CBs belong to a particular category of CBs called 'People's Banks' (Banche Popolari - PBs). Though they are 
legally co-operative companies, PBs differ from pure mutual banks (Banche di Credito Cooperativo, BCCs), as they have no constraints on the distribution of profits, that apply to BCCs. On the other hand, like BCCs, PBs voting rights are exercised according to the $1 \mathrm{H} 1 \mathrm{~V}$ principle, as opposed to the $1 \mathrm{~S} 1 \mathrm{~V}$ principle of JSBs. ${ }^{1}$ Finally, the Italian Banking Law (Testo Unico Bancario) does not force different viability between JSBs and PBs, while it envisions several limitations for BCCs (see Appendix, Table A1, for additional details). Summarizing, PBs can be considered a hybrid model between the pure co-operative model (same securityvoting structure) and the joint stock model (no limits to profit distributions and to issue stocks), a sort of extreme public company enjoying a limited takeover discipline because of the different security-voting structure. ${ }^{2}$ This hybrid model, probably unique in the international setting, allows us to isolate the effect of different security-voting structures on a firm's value by comparing PBs and JSBs.

If the security-voting structure does not affect the value of equity, then there will be no relationship between the security-voting structure (1S1V vs. $1 \mathrm{H} 1 \mathrm{~V})$ and the market value of the bank. If this is the case, the decision to switch from PB to JSB should not produce any effect on the value of the traded shares. However, anecdotal evidence leads to question this independence and seems to support the idea that the $1 \mathrm{H} 1 \mathrm{~V}$ principle decreases the market value of PBs. On February 1, 2013 the announcement of a possible conversion of the PB Banca Popolare di Milano into a JSB led an increase of the share price of about $10 \%$; on February 12, 2013, when the dossier was analysed for the first time by the Board of Directors, the share price jumped an additional 7\%. On August 12, 2014, news that the Banca Popolare dell'Etruria's Board of Directors had instructed its Chairman to lead the process to change its legal form from PB to JSB resulted in a share price jump of about 8\%. On February 17, 2015,

\footnotetext{
${ }^{1}$ Constraints on profit distributions and the $1 \mathrm{H} 1 \mathrm{~V}$ principle are the two main characteristics of co-operatives (Becchetti, Ciciretti and Paolantonio, 2014)

${ }^{2}$ The threat of a hostile takeover is not completely absent since the Italian Law allows takeovers on PBs, but the effectiveness of the bid is subordinated to the transformation of the CB into a JSB by the target's shareholders.
} 
when the Italian government announced its intention to ban the $1 \mathrm{H} 1 \mathrm{~V}$ principle of PBs and convert them into JSBs, the price of all PBs gained an average of $10 \%$ (the compound return from the day of first rumours concerning this regulatory change to its final approval into a law was about $40 \%$ ). Of course, these examples are clues and not poofs of the relation between the security-voting structure and the market value of PBs and JSBs. In addition, these market reactions could mostly reflect the expected benefit from easier takeovers with the departure from the $1 \mathrm{H} 1 \mathrm{~V}$ principle.

Inspired by all these examples, our analysis questions if CBs and JSBs have a different market value and costs of equity, due to the different security-voting structure. We perform our comparison by analysing how share prices react to the announcement of new equity offerings. We deem that this kind of operation is ideal to test differences between CBs and JSBs with respect to the security-voting structure since the market reaction to the issue of new shares is not biased by alternative explanations such as takeover expectations or synergies from future mergers. As the Governor of the Bank of Italy noted in his Concluding Remarks of 2012, within listed banks 'the co-operative model may even make it more difficult to strengthen their capital' and it 'should be made easier for listed co-operative banks to turn themselves into joint stock companies, when their size and the nature of their operations make this necessary'. The limit to raising new equity capital for CBs pointed out by the Bank of Italy, could derive from the $1 \mathrm{H} 1 \mathrm{~V}$ principle that increase the cost of the equity financing. From this point of view, studying equity capital issues is an opportunity to ascertain if there is a relationship between different security-voting structures and the cost of equity. If the $1 \mathrm{H} 1 \mathrm{~V}$ rule discourages investors to supply new equity capital, then the market reaction to the announcement of a new equity issue should be more negative (or less positive) for CBs than for JSBs. 
Following this logic, we perform our empirical analysis in two steps. First, we test through an 'event-study' methodology for the existence of a significant market reaction to the announcement of a new equity offering and if this reaction is influenced by the securityvoting structure. Then, via a multivariate analysis based on regressions and matching methods, we ascertain if the security-voting structure still influences the market reaction after controlling for the operation, bank and market observable characteristics.

Overall, our empirical analysis supports our research hypothesis that the $1 \mathrm{H} 1 \mathrm{~V}$ principle makes it more difficult to raise new equity capital compared to $1 \mathrm{~S} 1 \mathrm{~V}$ principle. We deem that our analysis could be of interest for an international audience at least for two reasons. From a corporate governance perspective, as far as we know, there are no other empirical studies in the security-voting structure literature comparing the $1 \mathrm{H} 1 \mathrm{~V}$ and the $1 \mathrm{~S} 1 \mathrm{~V}$ principles on the ground of the market value of equity. While several scholars state that 'the governance framework of cooperative banks may hamper raising capital' (i.e. Gutiérrez, 2008; 15) empirical evidence supporting this claim is still sparse. From a policy maker's perspective, our results contribute to the demutualization literature (see Chaddad and Cook, 2004, and Erhemjamts and Phillips, 2012, among others) suggesting that the transformation of pure cooperative banks into the hybrid type represented by Italian PBs do not completely remove the obstacle to the collection of external equity capital.

The rest of the paper is organized as follows. Section 2 presents the related literature. Section 3 describes our data sample. Section 4 presents the results of our univariate and multivariate analyses. Section 5 presents a discussion of our main results. Section 6 concludes. 


\section{Related literature and hypotheses}

Our paper contributes to the literature on (i) security-voting structure, (ii) market reaction to the rights issues of banks, (iii) demutualization. As for the security-voting structure, we offer empirical evidence about a widespread although neglected deviation from the 1S1V principle: the $1 \mathrm{H} 1 \mathrm{~V}$ structure characterizing cooperative firms and its consequences for equity financing. Concerning the market reaction to Seasoned Equity Offerings (SEOs) of banks, we study rights issues, a less scrutinized way to raise new capital than public offers. Finally, for the demutualization problem, to the best of our knowledge, our research is the first attempt to analyse if the transformation of pure CBs into the hybrid type represented by Italian PBs can remove the obstacle to the collection of external equity capital. We present below a brief literature review on these three topics.

\subsection{Security-voting structure and the 'one share - one vote' principle}

The $1 \mathrm{~S} 1 \mathrm{~V}$ rule is the bedrock principle of Anglo-Saxon corporate governance system where the distribution of capital rights ('cash flow rights') goes hand in hand with the control of the capital assets ('voting rights'). In the $1 \mathrm{~S} 1 \mathrm{~V}$ system, all shareholders have the same equal claims, and this should ensure a level playing field thanks to the market discipline. Market discipline can be a quite vague concept and it is less precise than the internal mechanism, but it consists of a set of potential owners seeking to acquire undervalued firms and earn aboveaverage returns on their investments in the middle and long term thanks to a more capable management, more active shareholders and better corporate governance mechanisms in place. However, market discipline does not eliminate inefficiencies nor the agency problems as in 
the real-world markets are not perfectly efficient, free from asymmetries and from structural constraints.

The OECD Principle of Corporate Governance (1999, 2004, and 2015) states that the basic shareholders rights should include the rights to (i) ownership registration, (ii) transfer of shares, (iii) information on the corporation, (iv) vote in the general shareholders meeting, (v) ability to elect/remove directors, and (vi) share the profits. One of the most debated and important aspect of corporate governance is the security-voting system and the distribution of the cash flow that can or cannot depend on the number of owned shares.

In their seminal contribution, Grossman and Hart (1988) and Harris and Raviv (1989) distinguish two classes of benefits from control: private benefits that the current management/incumbent obtain for themselves and the security benefits that are the total market value of the firm's securities and concluded that the $1 \mathrm{~S} 1 \mathrm{~V}$ is the optimal securityvoting structure to maximize the firm's value. Mainstream theory and anecdotal evidence see Manne (1965), Fama (1980), Jensen (1988), Scharfstein (1988) and others - support the idea that $1 \mathrm{~S} 1 \mathrm{~V}$ is the most effective security-voting structure in promoting the efficient allocation of resources and in mitigating the agency problems.

The security-voting system serves to elect directors and Easterbrook and Fischel (1983), Holderness, Kroszner and Sheehan (1999) sustain that the most important right attached to any share it is the right to vote on corporate matters. Burkart and Lee (2008) state that the allocation of voting rights across shares 'matters because it determines the balance of power among shareholders as well as their leverage over management'. The stakeholder theory suggests that the interest of all stakeholders (i.e. customers, employees, supplier et cetera) should be taken into consideration for the long-term success of the business. However, only the shareholder can vote because they have the residual claim of the firm's income as 'they 
stand to gain or lose almost the whole value of modest fluctuations in the fortunes of the firm' (Easterbrook and Fischel, 1985).

The security-voting system and the kind and type of ownership structure can be endogenous or path dependent. Bebchuk and Roe (1999) explain that these paths are (i) 'structure driven' which is determined by the initial ownership model and structure in an economy, and (ii) 'rule driven' which is focused by the laws and regulation in an economy. These authors sustain that the initial condition matter in creating and in maintaining the differences in the equity ownership and in determining the pace of future change because they 'locked' the company into a particular path. This means that the current corporate structure of a company is influenced by 'a priori' particularities and these differences tend to persist at later points in time. As such, this assumption undermines the Darwinian or neoclassical theory that only the best and the fittest would survive and prosper and in doing so it raises the question if only the $1 \mathrm{~S} 1 \mathrm{~V}$ is desirable for an efficient market. These constraints are also highlighted by a seminal work of La Porta, Lopez-de-Silanes, Shleifer and Vishny (2000) where the costs for the control depend not only on a corporate basis but also at a country-level because greater investor protection may facilitate the access to external sources of finance.

Hansmann and Kraakman (2001) spark an academic debate around which voting system is superior and if we would witness a global convergence towards the $1 \mathrm{~S} 1 \mathrm{~V}$. They paraphrase a work of Fukuyama (1991) titling their article the 'The end of History for Corporate Law' arguing that 'the triumph of the shareholder-oriented model of the corporation over its principal competitors is now assured'. However, recent events have largely demonstrated that the convergence towards liberal democracies, market-oriented economies and corporate governance models is not inescapable. 
Deviations from 1S1V are common outside the UK and the USA, particularly in bank-centred countries and in economies dominated by family-controlled conglomerate but even in the Anglo-Saxon countries this principle 'is often violated in reality' (Bukart and Lee, 2008). Indeed, in the United States, which is perceived to be abiding by the $1 \mathrm{~S} 1 \mathrm{~V}$ rule, there are significant implementations of Control Enhancing Mechanisms (CEMs). For example, in 1986 the New York Stock Exchange (NYSE) ended its prohibition of disallowing the listing of the securities of companies with dual class of common stock introduced in 1926 to better compete against American Stock Exchange and NASDAQ that permitted dual class shares that are popular during IPOs in particular sectors (i.e. technology).

The Report on the Proportionality Principle in the European Union (2007b) undertaken by a consortium led by ISS Europe showed that CEMs are relatively common in Europe but the implementation greatly differs from country to country, for example, France and Sweden have the highest proportion (80\%) while the United Kingdom the lowest (5\%).

The main objective in allowing Control Enhancing Mechanisms (CEMs) is the desire of controlling shareholders to retain control of the company without having to invest the proportional cash and as such preserve ('lock-in') the company control of the incumbents. Control Enhancing Mechanisms (CEMs) deviate from the 1S1V principle - proportionality between ownership and control rights - via the following instruments: (i) multiple voting right shares, (ii) non-voting shares, (iii) non-voting preference shares, (iv) pyramid structures, (v) priority shares, (vi) depository certificates, (vii) voting rights ceilings, (viii) share transfer restrictions, (ix) supermajority provisions, (x) partnerships limited by shares, (xi) golden shares, (xii) cross-shareholdings and (xiii) shareholders agreements. Others may include to (i) forbid the entrance of certain type of shareholders, (ii) appoint board members a priori, or (iii) allow special rights to amend the company statute. 
In principle, it seems logic and desirable that the shareholders who supply equal amounts of capital or hold equal claims should also have the same opportunity to influence the company's decisions Mainstream theory and practitioners suggest that when there is not a proportion of voting right and ownership then the incumbent (i.e. management/controlling equity holder) can extract private benefits at the expense of the non-controlling shareholders. DeAngelo and DeAngelo (1985), Zingales (1994) and others provide evidence companies that are practically non-contedible command a premium captured by the incumbent for its control that is not accrued to all shareholders. Bebchuk, Kraakman, and Triantis (2000) find that CEMs distort the incentive of the incumbents and raise the agency costs, Burkart, Gromb, and Panunzi (2005) argue that these mechanisms can increase the moral hazard and leads to inefficiencies while Claessens, Djankov, Fan, and Lang (1999) find that there is an expropriation from minority shareholder by the controlling shareholders with higher cashflow right.

However, in several cases the deviation from the $1 \mathrm{~S} 1 \mathrm{~V}$ principle can be in the best interest of the shareholders. For example, Grossman and Hart (1988) discuss the case when a familycontrolled company wishes to raise capital for alternative projects or diversity but does not wish to sell/loss the voting control. Lease, Netter, and Poulsen (1990) add also when the company has good growth potential and wishes to maintain cheap source of financing while Alvaro, Ciavarella, D’Eramo, and Linciano (2014) mention other advantages such as: (i) controlling shareholders can reach the same result via more opaque mechanisms such as pyramid structures and cross-holding companies; (ii) discourage an Initial Public Offer; (iii) dampen the acquisition of the full control of the company; (iv) discourage a takeover.

During the last decade, it seems that deviation from $1 \mathrm{~S} 1 \mathrm{~V}$ is not 'out of fashion' (Pajuste, 2005). On the contrary, the EU Impact Assessment (2007a) concludes that there is not 
sufficient incentive to harmonize different legislation and to make the $1 \mathrm{~S} 1 \mathrm{~V}$ principle compulsory, while the Aspen Institute (2009) recommended 'in exchange for enhancing shareholder participation rights, consider adopting minimum holding periods or time-based vesting'. This study was endorsed, among others, by the founder of Vanguard, the world's second-largest fund house with $£ 3.5$ trillion of Asset Under Management in 2018, and Warren Buffet, Chairman and CEO of Berkshire Hathaway, to avoid short-termism in allowing to drive a long-term agenda. CMEs should be pursued to encourage the long-term sustainable stewardship that will bring benefit to the shareholders but the departing from the $1 \mathrm{~S} 1 \mathrm{~V}$ shouldn't be discriminatory and/or lead to unintended consequences. For example, enhanced voting rights have (i) to be distributed not only to the company's founder and to other insiders but all investors should be eligible for, if they qualify, (ii) to cap the total number of additional votes, and (iii) to consider the different types of investors.

In literature, empirical researches assess if the deviations from the $1 \mathrm{~S} 1 \mathrm{~V}$ create/destroy firm value in estimating the relationship between CMEs and market value of outside equity via two different techniques. The first type measures the gap between the market value of outside equity and the 'excess' value created by the distortion of the $1 \mathrm{~S} 1 \mathrm{~V}$ principle. The second one, analyse the stock market reaction to changes in the CMEs. Academics and practitioners emphasise the role of disclosure obligation to better understand and assess such mechanism as well as to ensure accountability and openness on the premise of 'self-organisation' and that there is not a 'one size fits all'. Therefore, it is yet to be conclusively proved that $1 \mathrm{~S} 1 \mathrm{~V}$ protects against the extraction of private benefit, prevent from information asymmetry and reduce the agency costs and, in doing so, promotes the efficiency of business. There is a large body in literature about the $1 \mathrm{~S} 1 \mathrm{~V}$ principle but a paucity on its deviation to the rule of $1 \mathrm{H} 1 \mathrm{~V}$ and such deviations are becoming a common occurrence. 


\subsection{Market reaction to banks' equity issues}

Empirical research on banks' raising of equity is sparse and, to the best of our knowledge, no study considers possible differences in the relationship between security-voting structure $(1 \mathrm{H} 1 \mathrm{~V}$ vs $1 \mathrm{~S} 1 \mathrm{~V})$ and the stock price reactions to SEO announcements, as we present in this paper. $^{3}$

Mainstream literature - Loughran and Ritter (1997), Lee (1997), Eckbo, Masulis and Norli (2000), Jegadeesh (2000), Brav, Geczy and Gompers (2000), Mitchell and Stafford (2000), Hauser, Kraizberg and Dahan (2003), Lemmon and Zender (2004), Jiao and Chemmanur (2005) and others - empirically shows that the market reaction to raising new capital is, almost always, negative, and particularly in the Anglo-Saxon countries. The capital increase constitutes 'bad news' for most investors signalling (i) overvalued shares, (ii) lower future profitability, and/or (iii) that insiders waste the new funds in negative NPV projects and/or maximise their own utilities. Mainstream literature highlights that the reasons behind the unprofitable new investments and the misuse of these proceeds are attributed to (i) asymmetric information, (ii) agency cost, (iii) 'Merton model' that is the relationship between current shareholders and other investors.

\footnotetext{
${ }^{3}$ If the company shares are already traded in the secondary market, then the issue of additional securities is known as a 'Seasoned Equity Offering' (SEO). The SEO discount is the difference between the closing stock prices during the last trading day prior to the announcement and its SEO offer price while the SEO underpricing is the difference between the SEO offer price and the closing stock price of the first trading day after the announcement. There are different SEO offer types (i.e. accelerated book-built offering, bought deal, fully marketed offering, competitive bid, privately negotiated, rights offer et cetera) according to the target market and the speed of offer. Our paper investigates the rights offer as the new shares are sold to existing shareholders (independently of the speed of offer). In rights offers, current shareholders are given the option to buy newly issued shares on a pro rata basis, usually at a discount to the current market price of the stock. If there are unsubscribed shares, then the overallotment option offers to the current shareholders the right to buy additional shares on pro rata before they are sold to external investors. The US market has been traditionally dominated by fully marketed SEOs while the European continent is characterized by rights offers.
} 
The theory of the asymmetric information between insiders (managers or dominant shareholders) and outsiders (market or minority shareholders) is related to the so-called signalling theory (Leland and Pyle, 1977; Allen and Faulhaber, 1989; Welch, 1989; Myers and Majluf, 1984; John and Williams, 1985; Miller and Rock, 1985), to the agency theory (Jensen and Meckling, 1976) as well as to the capital structure theory (Dittmar, 2000; Lie, 2002) and contributes explaining the market reaction to the raising of capital. Put differently, the asymmetric information between the insiders, that are aware of the future company earnings, and the outsiders, that can only estimate these future earnings based on public information available in the market, lead the latter to believe that the issue of new shares is a negative signal. The insiders would choose equity financing only if the current share price is higher than its 'fair value' or if they are expecting future losses and not more earnings. These theories predict that managers use the SEOs to signal their belief that the firm's shares are overvalued. As such, the greater the risk of information asymmetry between insiders and outsiders, the greater is the (expected) negative market reaction of the news of new shares. Issuers often anticipate this negative market reaction by offering the new shares at a discounted price: Mola and Loughran (2004) find an average discount of 3\% in a sample of 4,814 U.S. SEOs.

Several sectors and companies are less likely to suffer from the asymmetric information, for example the regulated ones, and the banking industry is heavily regulated. Loderer, Cooney, and Van Drunen (1991) note that there are finite price elasticities after the announcement of SEOs by regulated firms while Keeley (1989) finds a negative market reaction upon the announcement of a SEO by undercapitalised bank, relative to their capital requirements, compared to the well-capitalized ones. However, Krishnan et al. (2010) note the same negative market reaction to SEO announcements for both under-and-well capitalized banks. 
In the case of banks, the overvaluation signal may be contested when the equity offer is forced by a regulator. Regarding the 'voluntary' and 'involuntary' equity issues, Cantor and Johnson (1992) find that there is a long-term increase of the ordinary's share price if the US banks were well capitalized while Wall and Peterson (1991), Cornett and Tehranian (1994) find a negative market reaction following the news of a bank's SEO. Specifically, Cornett and Tehranian (1994) discover a statistically significant drop only if the equity offer is a voluntary move but not when it is forced by the bank's regulator ('involuntary') to shore up the capital reserves. They suggest that the 'voluntary' offers might increase the probability of opportunist behaviour by managers in issuing overvalued stocks, but this does not happen when the time of raising equity capital is decided by a third party. Ergungor et al. (2005) find the same negative market reaction for the voluntary or involuntary issues.

The separation of ownership and control (Jensen and Fama, 1983) is the root cause of the agency problems. Jensen, Crutchley and Hudson (1994), Jung, Kim and Stulz (1996), Betker and Alderson (2000), Howe and Su (2001), Barnes and Walker (2006) find a negative share reaction of the announcement of SEO or of forced warrant exercise (similar of the seasoned equity offering) that are linked with the cost of managerial discretion. This happens when there is a misalignment of interests and incentives between the principal (shareholders) and the agent (management). Baumol (1959), Jensen (1986), Morck, Shleifer, and Vishny (1990), Malmendier and Tate (2005) point out that managers can act in this way because increasing the firm size could serve to subsequently raise their pay or serve their private interests in other ways. Investors realise this and interpret the announcement as bad news. In doing so, they revise their estimates of stock downwards (see, e.g., Asquith and Mullins, 1986; Masulis and Korwar, 1986; Mikkelson and Partch, 1986; Kim and Purnanandam, 2014).

Merton (1987) states that when 'the firm can use the underwriting to both raise new capital 
and increase its investor base' so that a SEO is an opportunity to increase the investor recognition of the firm as the awareness and familiarity with these shares will increase their demand. The 'Merton model' also suggests that with the proceeds of the equity offering there is a wealth transfer from the current shareholders to the debt holders or to the insurers of bank debt. Elyasiani, Mester and Pagano (2014) note that this problem is exacerbated if the new capital is senior to existing shareholders as it happened with the Troubled Asset Relief Program (TARP) investments in the Unites States aimed to recapitalize troubled financial institutions.

The market reaction could be different when considering rights issues, according to the ownership structure of the issuer. Marisetty, Marsden and Veeraraghavan (2007) find a more negative market reaction for firms with a dominant family, for fear that the proceeds of the rights issue will be misused for the benefit of the controlling shareholder ('tunnelling'). Gao and Mahmudi (2008) find that firms with larger institutional investors have better SEO outcomes, tend to issue a smaller size of equity, and are more likely to complete announced SEO deals. Chemmanur, He and Hu (2009) find that smaller SEO discounts are associated with the presence of large institutional investors that possess better private information about the firm. However, D’Mello et al. (2010) find that announcement returns are positively and significantly associated with institutional ownership concentration and with institutional ownership levels. Hoje, Yongtae and Dongsoo (2012) argue that weak corporate governance decreases information credibility. Once again, an empirical analysis of the stock price reaction to SEO announcements by a particular governance model would highlight if this model is considered weak and, as such, if it could negatively affect the investors' confidence and the cost of raising new capital. Indeed, Kim and Purnanandam (2014) show that a negative market reaction raises the concern about the usage of the SEO proceeds if there is in place a weak governance structure. Roskelley and Gokkaya (2011) note that the stock price 
of the dual-class issuers significantly underperforms its single-class issuer peers in the SEO's post-issue years.

Spamann (2010) note that the rights offerings are mandatory in several European countries because they allow the current shareholders to avoid dilution of their ownership in the company. When the equity issue includes subscription rights - that is meant to be addressed exclusively to the current shareholders - then all the above explanations (overvalued shares and Merton theory) for a negative market reaction, but agency costs, should be put aside, unless the majority shareholders (insiders) decide not to exercise the subscription rights but still maintain the company's control.

Massa, Vermaelen and Groen-Xu (2013) note that most of the existing literature on SEOs is mainly country specific, which is partly due to the wide variation in national laws and listed regulations across countries. For example, in Italy, the most popular equity issue is with subscription rights; the right is tradable so that the shareholders who do not wish to exercise their right can sell it in the secondary market. However, the company can restrict its tradability when managers believe that the stock is undervalued so that they are reluctant to issue additional shares to new shareholders as this will dilute the wealth of the current firm's owners. In the rights issue, the offer price can be markedly lower than the current price with diluted effects on the share value. On the contrary, in an offering without subscription rights the issue price is aligned with the market price of shares.

Hietala and Loytyniemi (1991) interpret the rights offering as a signal of a future increase of dividends. The bigger these future dividends, the lower the mark-up pegged by the issuer. If the dividend per share is unchanged after the rights issue, then there is an increase of the total dividends paid out over the year to its shareholders that is more than proportional than the amount invested in the company with the subscription of the new shares. Within this 
framework, the news of a rights issue can be 'good news' for the shareholders, especially when the additional shares were offered with subscription rights for free or with the subscription rights to be partially free and partially upon payment. The empirical evidences on the Italian market confirm this theory (Bigelli, 1996). Bigelli (1995) finds a more negative market reaction when there is a dispersed share ownership than with presence of blockholders. This happens when there is not the 'dividend' effect mentioned above and when the current shareholders entirely subscribe to the rights issue.

All things being equal and without the dividend rate effect, applied to the above theories for Italian banks, we hypothesise that the PB's decision to offer new equity via a rights issue upon payment, prompts a market reaction on its share price more negative or less positive than the one observed for a similar choice by a JSB. This would reveal that the $1 \mathrm{H} 1 \mathrm{~V}$ rule is associated to higher costs of equity when compared to the $1 \mathrm{~S} 1 \mathrm{~V}$ rule. Such a result contributes to the current debate on whether the restrictions on ownership and voting rights characterising CBs do or do not jeopardise and weaken the bank's ability to raise external (and cheaper) equity funds.

\subsection{Co-Operative Banks and demutualization}

In $\mathrm{CBs}$ voting rights are allocated on the principle of $1 \mathrm{H} 1 \mathrm{~V}$ to facilitate the social cooperation and the synthesis of what different groups (i.e. bankers and customers) have in common. This is an alternative approach to the JSBs where each share carries the right to vote $-1 \mathrm{~S} 1 \mathrm{~V}$ principle - that is believed to be better suited to deliver the shareholder value maximisation. In $\mathrm{CBs}$, there is one vote per member irrespective of the financial commitment to the company in order to avoid a 'disproportional' influence by one shareholder. As such, the 
ownership does not come from capital but from a membership based on purchasing the company's products and/or services.

CBs were established to meet the needs of working categories (i.e. farmers, workers, craftsmen and small commercial businesses) that were overlooked by banks during the second half of the nineteenth century. Their business model was meant to grant credit mainly to their members and/or to individuals and to small and medium enterprises in a restricted geographical area. Indeed, they pursued economic benefits for shareholders by providing an active role in building the societies in which their members live. Petersen and Rajan (1994), Pittaluga et al. (2002), Goglio (2007), Palomo Zurdo and Sanchis Palacio (2008) investigate the impact of CBs in their local community.

CBs have $20 \%$ of market share in the European financial system, but they reach a staggering $51 \%$ in France, $31 \%$ in Finland, 30\% in Austria and in the Netherlands, $27 \%$ in Italy and 25\% in Germany. The Association of European Cooperative Banks (AECB) represents 4,200 CBs, serving 149 million clients - including 12 million SMEs - with $€ 4.2$ billion in total assets in 2011.

A process of demutualization has been taking place for some decades in many countries, involving CBs and other mutual organizations on a voluntary or mandatory basis. The conversion to stock ownership of many Savings and Loan Associations and mutual insures (Chaddad and Cook, 2004; Erhemjamts and Phillips, 2012) are examples in the U.S. context; similar examples can be found in Australia, Great Britain, and South Africa (Chaddad and Cook, 2004). In Italy, recent laws imposed the transformation of PBs with total assets greater than $€ 8$ billion into JSBs (DL 24/1/2015, n. 3, and Law 24/3/2015, n. 33) and the aggregation of pure mutual banks (Banche di Credito Cooperativo - BCCs) under the strategic coordination of a JSB Holding Company (DL 14/2/2016, n. 18 and Law 8/4/16 n. 49). 
As we mention above, our work contributes to the debate on demutualization (Birchall, 2001; Moore and Kraatz, 2011). As Chaddad and Cook (2004) note demutualization 'refers to changes in the ownership structure of user owned and controlled organizations from a mutual to a for-profit, proprietary organization'.

Analysing the demutualization of 29 mutual Savings and Loan (S\&L) Associations, Hadaway and Hadaway (1981) document a positive economic impact in terms of profitability, risk tolerance and growth potential following conversions to stock companies.

Focusing on the after-conversion financial performance of S\&L Associations, Masulis (1987) and Cole and Mehran (1998) find that demutualization induces increases in stock prices.

Chaddad and Cook (2004) document waves of demutualization in the US and provide a critical analysis of the empirical literature on demutualization in the S\&L, and insurance industries. Their general finding is that 'demutualization is in general efficiency enhancing but may cause adverse effects on members' well-being and industry performance'. The authors state that '[o]perational and financial performance is enhanced as converting to a stock company from a mutual structure offers the possibility of raising capital to ameliorate perceived financial constraints and the ability to provide high-powered incentives to managers and employees'.

However, as Chaddad and Cook (2007) note 'conversions are partly motivated by selfinterested managers and directors'.

Recent works present other counterarguments to demutualization. For example, Ayadi et al. (2010) note that 'it is systemically beneficial to have [stakeholder value] banks in general, and cooperatives in particular, in a financial system'. The authors continue by noting that '[i]n many respects it is the mix of different types of institutions that is important (the 
biodiversity argument) as much (if not more so) than the merits of any particular ownership structure or business model'. ${ }^{4}$

Chaddad and Cook (2004) also observe that demutualization is creating cooperative hybrids that allow cooperatives to acquire outside capital. Mutual holding companies (MHCs) are examples of these cooperative hybrids. As the authors note '[t]he MHC structure allows the mutual to access outside equity without relinquishing member control'.

Examining the U.S. life insurance industry, Erhemjamts and Leverty (2010) find that full demutualization is typically chosen for efficiency and access to capital reasons, while the MHC form is generally chosen for tax savings.

Erhemjamts and Phillips (2012) confirm these results. The authors' findings are '[...] consistent with the access to capital hypothesis being the primary motivating factor for fully demutualizing insurers, while the tax incentives appear to be a significant motivation for MHC conversions'.

While Italian PBs are not MHCs in a strict sense, they may be considered as a form of cooperative hybrids, since, as we mention above, they share the same voting system as CBs and are free to distribute dividends and issue stocks like JSBs. Thus, our analysis contributes to the literature on cooperative hybrids. Specifically, the characteristics of PBs allow us disentangling the specific effect of the $1 \mathrm{H} 1 \mathrm{~V}$ principle.

\section{Data}

Our dataset includes all rights issues of new shares and/or similar securities (convertible bonds and warrants) that were announced by Italian listed banks during the period 1989-2014.

\footnotetext{
${ }^{4}$ We deem important mentioning this strand of literature, but we do not discuss it in depth as doing so would take us too far afield with respect to the central topic of our work.
} 
Usually, the new shares are subscribed at a predefined price, but in some rights issues, existing shareholders received all, or a part of, the new shares for free (i.e. the issuing price is zero) realizing, de facto, a pure or partial stock split. The sample does not include financial transactions which lead only to a new face value of the shares as well as the script dividend and the issues of shares and/or convertible bonds reserved only to new shareholders (which, however, are rare in Italy). From this initial sample of 122 cases, we excluded eight rights issues because of the lack of historical price time series (Interbanca), the rights issue transferred the ownership control of the company (Banca Profilo), the rights issue was approved to rebuild the equity capital eroded by relevant losses (Banca Italease), the exact date of the announcement was uncertain (5 events).

We gathered information on each rights issue from the BitStat publication, which supplies detailed statistical information on all markets organised and managed by Borsa Italiana Spa since 1999. We gathered additional data from the archives of the most important Italian financial newspaper, 'Il Sole 24 Ore'.

Table 1 describes the sample of 114 rights issues (Full Sample) distinguishing between rights issues pertaining fifteen PBs and twenty-five JSBs. Observations are grouped by the type of rights issue (upon payment, partially upon payment and for free), kind of issued securities (shares only or shares and other securities, shares only, other securities only) and a combination thereof (shares only or shares and other securities upon payment, shares only upon payment). The sample shows that $73 \%$ of the rights issues are upon payment, while the remaining $27 \%$ are partially upon payment or for free. The comparison between PBs and JSBs reveals that the issue of shares only is more frequent within the latter than the former. This result is initial evidence in support of our research hypothesis. 
For each observation in our dataset, we collected information concerning the rights issue, the bank involved in the operation, and the market condition. Furthermore, we collected the price rectifier factor by the Italian Association of Financial Analysts (AIAF), the relative issue size, the issuing-to-market price and overprice ratio. In addition to the type of bank that is announcing the operation, we registered its beta, price-to-book value, ROE and market size. Finally, we gathered information on the year of the rights issue and the market trend in the six months preceding the announcement. In the Appendix (Table A2), we describe with greater details all variables at our disposal.

\section{Results}

\subsection{Univariate analysis}

In this work, we use the event-study methodology (Brown and Warner, 1985) to determine the effect of the rights issue on the share prices. The event date, which we denote by $t=0$, is the date in which the approval of the rights issue is formally announced to the market. If the announcement occurred when the market was closed, we consider the following business day.

After defining the event date, we can calculate the abnormal returns (ARs). Formally, the abnormal return for the bank $i$ at time $t$ is

$A R_{i t}=r_{i t}-E\left(r_{i t}\right)$

where $A R_{i t}, r_{i t}$ and $E\left(r_{i t}\right)$ are the abnormal return, the observed return and the normal return respectively.

Normal returns are not directly observable and as such, we need to estimate them. We estimate normal returns using two approaches. With the first approach, we estimate normal 
returns as the returns of the benchmark index for the banking sector. The benchmark index that we use in our analysis is the MILAN COMIT BANKING - PRICE INDEX. We call the abnormal returns calculated using this first approach as 'sector adjusted abnormal returns'. With the second approach, we estimate normal returns through the market model using the Italian All Share index (MILAN COMIT GLOBAL + R - PRICE INDEX) to proxy for the market returns. The market model parameters are estimated via OLS regressions performed using data of the 100 trading days between $t=-130$ and $t=-31$ with respect to the event date. We call the abnormal returns calculated using this second approach as 'market model adjusted abnormal returns'.

For each rights issue, we estimate the abnormal return on the event day, $\operatorname{AR}(0)$, and in the day before the event day, AR(-1). In addition, to obtain an overall measure of market reaction around the event date we calculate cumulated abnormal returns (CARs) for the following event windows: $(-5,+5),(-3,+3),(-1,+1)$ and $(-1,+30) .{ }^{5}$ Once ARs and CARs are obtained for each rights issue, we calculate the average AR and CAR and test for their statistical significance following the approach in Boehmer et al. (1991) which accounts for eventinduced variance. $^{6}$

Table 2 shows the results of the event study. We show sector adjusted abnormal returns in Panel A and market model adjusted abnormal returns in Panel B. We run the event-study analysis for the full sample of rights issues and for several subsamples for which we perform mean difference tests. First, we distinguish the rights issues upon payment from those that are only partially upon payment or for free. Then, we distinguish the rights issues concerning

\footnotetext{
${ }^{5}$ While the CAR $(-1,+30)$ covers a long event window and is possibly influenced by confounding effects, we retain this figure since often some relevant details of the rights issue are made available to the market several days after the announcement day. Moreover, in the event-study literature long time span are not uncommon (i.e. Hauser, Kraizberg and Dahan, 2003).

${ }^{6}$ We have also made additional tests considering a bootstrap approach. Results remain qualitatively unchanged and are not reported for brevity.
} 
PBs from those concerning JSBs. For the latter comparison, we consider both the case of rights issues of shares only or shares and other securities, and the case of rights issues of shares only. In either case, we limit our analysis to the rights issues upon payment. ${ }^{7}$

The results in Panels A and B of table 2 are very similar, indicating that our findings are quite robust with respect to the method that we use to calculate abnormal returns. Aside from a few exceptions, a general result in the table is that CARs for PBs tend to be negative and lower than CARs for JSBs. For example, when focusing on the period from $t=-3$ to $t=+3$, we note appreciable differences between PBs and JSBs (especially with the market model). The difference between the CAR $(-3,+3)$ of PBs and JSBs is negative and statistically significant when we consider both the rights issues of shares and other securities and the rights issues of shares only. The results of this preliminary analysis, based on a simple comparison between PBs and JSBs, seem thus consistent with our research hypothesis. However, these results could be attributed to other differences between PBs and JSBs, not concerning the securityvoting structure. In the next section, we perform a multivariate analysis to control, or at least mitigate, the potential confounding effects of these differences.

\subsection{Multivariate analysis}

In the previous section, we note that the difference of the market reaction around the event day between PBs and JSBs is negative and statistically significant. However, as we noted above, this difference could be due to idiosyncratic characteristics of PBs and JSBs that do not concern the security-voting structure.

\footnotetext{
${ }^{7}$ We distinguish rights issues upon payment from those totally or partially for free because the market reaction to their announcement could be different. A free issue of share is, de facto, a stock split and the literature has documented positive abnormal returns around announcements and ex-split days (Grinblatt, Masulis and Titman, 1985; Lakonishok and Vermaelen, 1986; Lamoureux and Poon, 1987; Ikenberry, Rankine and Stice, 1996), while the reaction to stock issues upon payment is mainly negative in fully marketed SEOs or mixed in rights offers (see paragraph 2.2). Different market reactions are also observed between SEOs and convertible debt offerings (Loncarski, Horst and Veld, 2006).
} 
In Table 3, we provide mean (and median) values for rights issues, bank and market observable characteristics distinguishing between PBs and JSBs. We find significant differences in mean values of several characteristics, a result that suggests that the two subgroups are heterogeneous. The negative and statistically significant difference between the CARs around the event day of PBs and JSBs may be, at least in principle, attributable to this heterogeneity.

To mitigate this risk and control for this heterogeneity, we perform a multivariate analysis. Since the results of our univariate analysis are similar for CARs calculated on different event windows, we perform our multivariate analysis using the CAR $(-3,+3)$ only. ${ }^{8}$ We consider two approaches. The first approach is based on a regression analysis, where we regress the dependent variable, CAR $(-3,+3)$, on a dummy variable indicating if the rights issue concerns a PB (rather than a JSB) and a set of control variables used by similar studies in the literature on new shares issues discussed in section 2 (for details see the Appendix - Table A2). The estimated coefficient on the PB dummy indicate the difference between the CAR $(-3,+3)$ of PBs and JSBs after conditioning on (controlling for) the set of control variables. The second approach is based on matching estimators, where we compare the CAR $(-3,+3)$ of PBs with those of JSBs that are as similar as possible in terms of control variables. To do so, we use two methods based on similarity measures: nearest-neighbour matching and propensity-score matching. ${ }^{9}$ With the nearest-neighbour matching, we calculate the Mahalanobis distance between pairs of observations with respect to the control variables and then match each PB to comparable JSBs. Than we calculate the average difference between the CARs of PBs and matched JSBs. In Propensity-score matching, matches are made on propensity scores that are

\footnotetext{
${ }^{8}$ Results using other event windows are available upon request.

${ }^{9}$ Of course, legal forms (PBs vs. JSBs) are not randomly assigned. In using nearest-neighbour matching and propensity-score matching, we thus assume that all the variables affecting both the legal form and CARs are included in the model, so that the outcomes can be considered conditionally independent of the treatment (or at least that, after controlling for bank characteristics, residual individual-specific idiosyncrasies are negligible).
} 
obtained by estimating logit models for the PB dummy where the control variables are used as independent variables.

In Table 4, we show the results of the regression analysis. We estimate twelve models: six models where the dependent variable is the sector adjusted CAR $(-3,+3)$ and six models where the dependent variable is the market model adjusted CAR $(-3,+3)$. The models differ in terms of the samples that we use in the estimation and model specifications, which are indicated in the heading of the table. Models 1, 2, 7 and 8 use all the 114 observations; models 3, 5, 9 and 11 are estimated in the subsample including the rights issues of shares upon payment (with or without the issue of other securities); models 4, 6, 10 and 12 are estimated in the subsample including the rights issues of shares only upon payment. The regression equations of models 1 and 7 include all independent variables with the exclusion of the two variables, issuing-tomarket price and overprice, that are available for a limited number of rights issues. Since the number of independent variables in Models 1 and 7 is high if compared to the sample size, we estimate models 2 and 8 that are restricted models chosen by a general-to-specific modelling approach starting from models 1 and 7 (Candela et al., 2016). The general-tospecific modelling approach is used also for choosing the control variables in the restricted models 3-6 and 9-12, even though these models are based on different initial specifications. Models 3, 4, 9 and 10 are restricted models chosen from specification A, which add the variable issuing-to-market price to the control variables; models 5, 6, 11 and 12 are restricted models chosen from specification $\mathrm{B}$, which add the variable overprice to the control variables.

The results in Table 4 are consistent with those of our univariate analysis. The main finding is that when comparing issues of shares upon payment (with or without the issue of other securities as in models $3,5,9$ and 11 , or shares only as in models $4,6,10$, and 12 ), the coefficient on the PB dummy is negative and significantly so in all model but model 3 . This 
first results offers support to our hypothesis that the security-voting structure has implication on the issue of new shares. When pooling all observations together despite of the type of rights issue (upon payment, partially upon payment and for free) and kind of issued securities (shares only or shares and other securities, shares only, other securities only), as in models 1 , 2, 7 and 8 , the PB dummy is not significant possibly due to heterogeneity in the types of events that, as already noted, can elicit mixed market reactions. These results are robust across models, regardless of the model specification, number of observations and the way in which CARs are computed. As for the control variables, we document that, when significant, the AIAF price rectifier factor, the relative issue size, the price-to-book value, the return on equity, and the market size are positively related with CARs. CARs tend also to be more positive after 2007. On the other hand, the issuing-to-market price and overprice ratio tend to be negatively related with CARs. While these variables are not of primary interest in our study as they serve as control variables in recreating a ceteris paribus condition, encouragingly their signs are mostly consistent with economic reasoning and previous empirical works.

Tables 5 and 6 show the results based on the matching estimators. In Table 5, we consider the nearest-neighbour matching estimator; in Table 6, results are based on the propensity-score matching estimators. The results in Tables 5 and 6 substantially confirm those based on the regression analysis as the average effect associated to PBs is negative and significant in most models. After controlling for the differences in the observable characteristics of PBs and JSBs, the results are consistent with our research hypothesis. 


\section{Discussion}

The univariate and multivariate analyses in the previous section support our hypothesis that the $1 \mathrm{H} 1 \mathrm{~V}$ principle makes it more difficult raising new capital compared to $1 \mathrm{~S} 1 \mathrm{~V}$ principle. Several explanations exist for this finding.

As noted in the literature review section, a negative market reaction following new shares issues can be explained in terms of asymmetric information, 'Merton model', and agency costs. When equity issues include subscription rights and are aimed primarily at existing shareholders as in our empirical analysis, explanations based on the first two theories do not apply well. One possible explanation for the differences in rising new capital for PBs and JSBs is that their security-voting structure imply different agency costs of equity. In principle, agency costs of equity may stem from two possible conflicts of interests between principal (outsider) and agent (insider): (i) managers-insiders versus shareholders-outsiders, or (ii) majority-insider shareholders versus minority-outsider shareholders (Hillier et al., 2013, ch.2). The first situation occurs when the voting rights are dispersed among several shareholders, so that top managers have a major role in running and controlling the company. This conflict applies to JSBs with widespread ownership (public companies) and to PBs (due to the $1 \mathrm{H} 1 \mathrm{~V}$ principle). In this situation, the control is mainly exercised by senior managers, and specifically the CEO. Given the absence of majority (or dominant) shareholders, the CEO can influence the composition and the decision of the Board of Directors. The second situation typically applies to JSBs with concentrated ownership. In this case, most voting rights are owned by a single shareholder (or a restricted syndicate of shareholders) who, by the 1S1V principle, appoints managers and strongly influences their decisions. In the Italian context, all listed JSBs have a clear number of dominant shareholders that appoint the majority of the Board of Directors. In other words, during the years of our analysis, no listed JSB can be, 
strictly speaking, classified, as a 'public company'. This situation facilitates the identification of the two types of conflicts: the conflict between managers-insiders versus shareholdersoutsiders would mainly apply to PBs, since no listed JSB has a widespread ownership; the conflict between majority-insider shareholders versus minority-outsider shareholders would mainly apply to JSBs. Considering these premises, our results seem to suggest that the agency costs of equity are greater for PBs than for JSBs, making new capital issue more expensive for PBs, ceteris paribus.

Other explanations for our findings can be found in the literature on CBs. While the concepts of $\mathrm{CB}$ and $1 \mathrm{H} 1 \mathrm{~V}$ are theoretically different, they are observationally equivalent in most practical and empirical applications. For example, in our sample, all listed banks with a 1H1V security-voting system are PBs, a special category of CBs that share all the characteristics of JSBs but the voting system (that they share with CBs instead). Thus, the literature on the limit of CBs can be at least partly borrowed to explain differences between $1 \mathrm{H} 1 \mathrm{~V}$ and $1 \mathrm{~S} 1 \mathrm{~V}$ when rising new capital. While several authors empathize the pros of CBs, other authors (e.g. De Bonis, Manzone and Trento, 1994; Mosetti and Santella, 2000; Pittaluga et al., 2002; Labie and Périlleux, 2008) note that CBs have issues as well: managers are generally inefficient because they are not bound by market rules; investment decisions are distorted; there is a minimal number of members necessary to reach a minimal level of assets; formation of monopolies. Salvatore Rossi, General Manager of the Bank of Italy, in his speech addressed to the Finance Committee of the Lower House of the Parliament on 17 February 2015 stressed the opaqueness of the relationship between managers and members/shareholders within this model. All these negative aspects, which of course are all related to the agency costs mentioned above, can make investors reluctant to invest and explain our results that raising new capital for PBs is more difficult than for JSBs. 
After examining some possible explanations of our results, we now present some implications. Our results have implications from a corporate governance and policy maker's perspective, and especially for the literature on demutualization (Chaddad and Cook (2004) and Erhemjamts and Phillips (2012)). We offer empirical evidence that, as claimed by Gutiérrez (2008), the governance form of CBs based on the 1H1V principle makes raising new capital more difficult. This finding seems to contrast with the evidence that CBs and the $1 \mathrm{H} 1 \mathrm{~V}$ principle are still widespread all over the world but is consistent with the process of demutualization that has gradually involved several countries in the last decades. This process involves $\mathrm{CBs}$ and other mutual organizations and is achieved either on a voluntary or mandatory basis. As Chaddad and Cook (2004) note, this process of demutualization is creating cooperative hybrids that allow cooperatives to acquire outside capital. Italian PBs may be considered as a form of cooperative hybrids, since they share the same securityvoting structure as CBs and are free to distribute dividends and issue stocks like JSBs. In this sense our results contribute to the demutualization literature suggesting that the transformation of pure co-operative banks into the hybrid type represented by Italian PBs do not completely remove the obstacle to the collection of external equity capital.

Of course, the institutional context that we analyse may have influenced our results. However, several studies on the relationship between corporate governance and institutional context show that the main characteristic for classifying countries is whether they belong to the common law or civil law group (Beny 2008; La Porta, Lopez-de-Silanes, Shleifer, and Vishny 1997, 1998, 2000b; La Porta, Lopez-de-Silanes, Shleifer 1999, 2008). The common law/civil law divide is very important as the heterogeneity of institutional characteristics is much lower within groups than between groups. In this sense, the common law/civil law division encompasses other differences in institutional characteristics. For this reason, we believe that, although with different intensities and nuances, our results can be easily 
extended to most civil law countries. This is especially true for the civil law countries in the continental Europe as all countries belonging to the European Union mostly share the same market rules and level of shareholders protection. With lower confidence and greater caution, we could extend our results to the common law context at least for those countries where other forms of shareholders protection are not implemented to eliminate any potential bias generated by the $1 \mathrm{H} 1 \mathrm{~V}$ system.

Future research could investigate the causes of the different market reaction following new equity issues of CBs, characterized by the $1 \mathrm{H} 1 \mathrm{~V}$ principle, and JSBs, characterized by the $1 \mathrm{~S} 1 \mathrm{~V}$ principle, and in particular the negative market reaction for CBs. The agency costs theory is one of the candidates to explain this finding. To better investigate this explanation based on agency costs, further empirical studies should consider, in addition to CBs and JSBs with concentrated ownership as we do, also JSBs with widespread ownership that, as we noted, are extremely rare in Italy. In doing so alternative explanations based only on the corporate legal form would be excluded and the contribution of the security-voting system to the negative reaction following new equity issues would be identified with greater precision.

\section{Conclusions}

In this paper, we test if the $1 \mathrm{H} 1 \mathrm{~V}$ principle of CBs and the $1 \mathrm{~S} 1 \mathrm{~V}$ voting system of JSBs imply different costs of equity. To do so, we use a unique dataset including all rights issues of new shares and other equity-like securities (convertible bonds and warrants) announced by Italian listed banks between 1989 and 2014 and exploit the ideal setting provided by the Italian Banking Law that allows PBs to be listed in the market. While PBs share the 1H1V principle with pure CBs, like JSBs, they do not have any constraints on the distribution of 
profits and can be listed in the market. Thus, the PB hybrid model offers a unique chance to isolate the effects of different voting systems.

Our empirical results, based on an event-study analysis, show that the difference in the overall effect following rights issue announcements for PBs and JSBs tend to be negative. Regression and matching estimators, while exploiting the ideal setting provided by the Italian Banking Law and increasing the generalization potential of our analysis, confirm this main finding after controlling for heterogeneity in the PB and JSB subsamples.

Our results offer support to the claim in several researches that the governance of CBs may be a limit to raising capital. Additionally, our results contribute to the literature on demutualization and cooperative hybrids, suggesting different costs of equity stemming from different security-voting systems and that the conversion of pure co-operative banks into hybrids (and in particular PBs) maintaining the $1 \mathrm{H} 1 \mathrm{~V}$ principle does not completely remove the obstacle to the raising of new equity capital. Furthermore, our results can help developing conceptual and theoretical models of agency costs, considering differences in governance and voting systems.

\section{References}

Adams R., \& Ferreira D. (2008). One Share, One Vote: The Empirical Evidence. Review of Finance, 12, 51-91.

Allen F., \& Faulhaber G.R. (1989). Signalling by Underpricing in the IPO Market. Journal of Financial Economics, 23(2), 303-323 
Alvaro S., Ciavarella A., D’Eramo D., \& Linciano N. (2014). La Deviazione dal Principio 'un'azione, un voto' e le Azioni a Voto Multiplo. Consob, Quaderni Giuridici, N. 5, 1-70, available at www.consob.it/documenti/Pubblicazioni/Quaderni_giuridici/qg5.pdf

Aspen Institute (2009). Overcoming Short-Termism: a Call for a more Responsible Approach to Investment and Business Management, available at https://assets.aspeninstitute.org/content/uploads/files/content/docs/pubs/overcome_short_state 0909_0.pdf

Asquith P., \& Mullins D.W. (1986). Equity Issues and Offering Dilution. Journal of Financial Economics, 15(1-2), 61-89.

Ayadi R., Llewellyn D.T., Schmidt R.H., Arbak E., \& Pieter De Groen, W. (2010). Investigating Diversity in the Banking Sector in Europe: Key Developments, Performance and Role of Cooperative Banks. Centre for European Policy Studies, available at http://ssrn.com/abstract $=1677335$

Barnes E., \& Walker M. (2006). The Seasoned-Equity Issues of UK Firms: Market Reaction and Issuance Method Choice. Journal of Business Finance \& Accounting, 33(1-2), 45-78.

Baumol W.J. (1959). Business Behavior, Value and Growth. Red ed. William J. Baumol. Harcourt, Brace and World.

Bebchuk L.A., \& Roe M.J. (1999). A Theory of Path Dependence in Corporate Ownership and Governance. Stanford Law Review, 52, 127-170.

Bebchuk L.A., Kraakman R., \& Triantis G. (2000). Stock Pyramids, Cross-Ownership and Dual Class Equity: the Mechanisms and Agency Costs of Separating Control from Cash-Flow Rights, in Concentrated Corporate Ownership (R. Morck, ed.) pp. 445-460, available at 
http://www.law.harvard.edu/faculty/bebchuk/pdfs/2000.Bebchuk-Kraakman-

Triantis.Stock.Pyramids.pdf

Becchetti L., Ciciretti R., \& Paolantonio A. (2014). Is There a Cooperative Bank Difference?

CEIS Working Paper, No 313, available at http://ssrn.com/abstract=2426190

Beny N. L. (2008). Do Investors in Controlled Firms Value Insider Trading Laws? International Evidence, 4 Journal of Law, Economics \& Policy, 267-310.

Berle A., \& Means G. (1932). The Modern Corporation and Private Property. New York, Macmillan Publishing Co.

Betker B.L., \& Alderson M.J. (2000). The Market Reaction to Warrant Calls: An Agency Cost Explanation, available at http://ssrn.com/abstract=255753

Bigelli M. (1995). Aumenti di Capitale con Diritto D’Opzione: Evidenze Empiriche per il Mercato Italiano, Il Risparmio, Vol. 4/5.

Bigelli M. (1996). Gli Aumenti di Capitale delle Società Quotate. Torino, Giappichelli Editore.

Birchall J. (2001). The New Mutualism in Public Policy. London, Routledge.

Boehmer, E., Musumeci, J., \& Poulsen, A. B. (1991). Event-study methodology under conditions of event-induced variance. Journal of Financial Economics, 30(2), 253-72.

Brav A., Geczy C., \& Gompers P.A. (2000), Is the Abnormal Return Following Equity Issuances Anomalous? Journal of Financial Economics, 56(2), 209-249.

Brown S.J., \& Warner J.B. (1985). Using Daily Stock Returns: The Case of Event Studies. Journal of Financial Economics, 14(1), 3-31. 
Burkart M., Gromb D., \& Panunzi F. (2006). Minority Blocks and Takeover Premia. Journal of Institutional and Theoretical Economics, 162(1), 32-49

Burkart M., \& Lee S. (2008). One Share - One Vote: The Theory. Review of Finance, 12(1), $1-49$.

Candela C., Castellani M., Pattitoni P., \& Di Lascio F.M.L. (2016). On Rosen's and Adler's hypotheses in the modern and contemporary visual art market. Empirical Economics, 51(1), $415-437$

Cantor R., \& Johnson R. (1992). Bank Capital Ratios, Asset Growth and the Stock Market. Quarterly Review, Federal Reserve Bank of New York, Vol. 3.

Chaddad F.R., \& Cook M.L. (2004). The Economics of Organization Structure Changes: A US Perspective on Demutualization. Annals of Public and Cooperative Economics, 75(4), $575-594$.

Chaddad F.R., \& Cook M.L. (2007). Conversions and Other Forms of Exit in US Agricultural Cooperatives, in Vertical Markets and Cooperative Hierarchies. Netherlands, Springer, 61-72.

Chemmanur T.J., He S., \& Hu G. (2009). The Role of Institutional Investors in Seasoned Equity Offerings. Journal of Financial Economics, 94(3), 384-411.

Claessens S., Djankov S., Fan H., \& Lang L. (1999). Expropriation of Minority Shareholders: Evidence from East Asia. World Bank, available at http://documents.worldbank.org/curated/en/283121468771272365/120520322_20041117181 051/additional/multi-page.pdf 
Cole R.A., \& Mehran H. (1998). The Effect of Changes in Ownership Structure on Performance: Evidence from the Thrift Industry. Journal of Financial Economics, 50(3), 291317.

Cornett M.M., \& Tehranian H. (1994). An Examination of Voluntary Versus Involuntary Security Issuances by Commercial Banks. Journal of Financial Economics, 35, 99-122.

DeAngelo H., \& DeAngelo L. (1985). Managerial Ownership of Voting Rights: A Study of Public Corporations with Dual Classes of Common Stock. Journal of Financial Economics, $14,33-69$.

De Bonis R., Manzone B., \& Trento S. (1994), La Proprietà Cooperativa: Teoria, Storia ed il Caso delle Banche Popolari, Banca d'Italia: Temi di Discussione 238.

Dittmar A.K. (2000). Why Do Firms Repurchase Stock? The Journal of Business, 73(3), $331-355$.

D’Mello R., Demiralp I., Subramaniam V., \& Schlingemann F.P. (2010). Are There Monitoring Benefits to Institutional Ownership? Evidence from Seasoned Equity Offerings. Journal of Corporate Finance, 17(5), 1340-1359

Easterbrook F.H., \& Fishel D.R. (1983). Voting in Corporate Law. Journal of Law and Economics, 26(2), 395-427.

Easterbrook F.H., \& Fischel D.R. (1985). Limited Liability and the Corporation. University of Chicago, Journal Articles, available at https://chicagounbound.uchicago.edu/cgi/viewcontent.cgi?article=2165\&context=journal_arti $\underline{\text { cles }}$ 
Eckbo B.E., Masulis R.W., \& Norli O. (2000). Seasoned Public Offerings: Resolution of the 'New Issues Puzzle'. Journal of Financial Economics, 56(2), 251-291.

Elyasiani E., Mester L.J., \& Pagano M.S. (2014). Large Capital Infusions, Investor Reactions, and the Return and Risk-Performance of Financial Institutions Over the Business Cycle. Journal of Financial Stability, 11, 62-81.

Ergungor Ozgur Emre, C.N.V. Krishnan, Ajai K. Singh, \& Allan A. Zebedee (2005). OfferPrice Discount of Bank Seasoned Equity Offers: Do Voluntary and Involuntary Offers Convey Different Information? Federal Reserve Bank of Cleveland, Working Paper, Vol. 5 (15), available at https://www.clevelandfed.org/newsroom-and-events/publications/workingpapers/working-papers-archives/2005-working-papers/wp-0515-offer-price-discount-ofbank-seasoned-equity-offers.aspx

Erhemjamts O., \& Leverty J.Y. (2010). The Demise of the Mutual Organizational Form: An Investigation of the Life Insurance Industry. Journal of Money, Credit and Banking, 42(6), 1011-1036.

Erhemjamts O., \& Phillips, R.D. (2012). Form Over Matter: Differences in the Incentives to Convert Using Full Versus Partial Demutualization in the US Life Insurance Industry. Journal of Risk and Insurance, 79(2), 305-334.

European Commission (2007). Impact Assessment on the Proportionality between Capital and Control in Listed Companies. Commission Staff Working Document, SEC 1705, available at http://ec.europa.eu/smart$\underline{\text { regulation/impact/ia_carried_out/docs/ia_2007/sec_2007_1705_en.pdf }}$ European Commission (2007). Report on the Proportionality Principle in the European Union, available at http://www.ecgi.org/osov/documents/final_report_en.pdf 
Fama E.F. (1980). Agency Problems and the Theory of the Firm, Journal of Political Economy, 88(2), 288-307.

Fukuyama F. (1991). The End of History and the Last Man, Penguin, UK.

G20/OECD (2015). G20/OECD Principle of Corporate Governance, available at https://www.oecd.org/daf/ca/Corporate-Governance-Principles-ENG.pdf

Gao H., \& Mahmudi H. (2008). Institutional Holdings and Seasoned Equity Offerings, available at https://papers.ssrn.com/sol3/papers.cfm?abstract_id=1125683

Goglio S. (2007). Local Credit and Territorial Development: General Aspects and the Italian Experience. Discussion Paper, No 27, Università degli Studi di Trento, Dipartimento di Economia, available at http://web.unitn.it/files/27_07_goglio.pdf

Grossman S.J., \& Hart O. (1988). One Share/One Vote and the Market for Corporate Control. Journal of Financial Economics, 20(1/2), 175-202.

Grinblatt M., Masulis R., \& Titman S. (1984). The Valuation Effects of Stock Splits and Stock Dividends. Journal of Financial Economics, 13(4), 461-490.

Gutiérrez E. (2008). The Reform of Italian Cooperative Banks: Discussion of Proposals. IMF Working Paper, No 74, available at https://www.imf.org/external/pubs/ft/wp/2008/wp0874.pdf

Harris M., \& Raviv A. (1989). The Design of Securities, Journal of Financial Economics, 24(2), 255-287.

Hadaway B.L., \& Hadaway, S.C. (1981). An Analysis of the Performance Characteristics of Converted Savings and Loan Associations. Journal of Financial Research, 4(3), 195-206. 
Hansmann H., \& Kraakman R. (2001). The End of History for Corporate Law, in Corporate Governance. Values, Ethics and Leadership, Taylor \& Francis Group.

Hauser S., Kraizberg E., \& Dahan R. (2003). Price Behaviour and Insider Trading around Seasoned Equity Offerings: The Case of Majority-Owned Firms. Journal of Corporate Finance, 9(2), 183-199.

Hietala P., \& Loytyniemi T. (1991). An Implicit Dividend Increase in Right Issues: Theory and Evidence. INSEAD Working Paper, available at https://flora.insead.edu/fichiersti_wp/Inseadwp1991/91-03.pdf

Hillier D., Ross S., Weaterfield R., Jaffe J., \& Jordan B. (2013). Corporate Finance. Maidenhead, UK, McGrow-Hill.

Hoje J., Yongtae K., \& Dongsoo S. (2012). Underwriter syndication and corporate governance. Review of Quantitative Finance \& Accounting, 38(1), 61-86.

Holderness C.G., Kroszner R.S., Sheehan D.P. (1999). Were the Good Old Days that Good? Changes in Managerial Stock Ownership since the Great Depression. Journal of Finance, 54(2), 435-469.

Howe J.S., \& Su T. (2001). Discretionary Reductions in Warrant Exercise Prices. Journal of Financial Economics, 61(2), 227-252.

Ikenberry D.L., Rankine G., \& Stice E.K. (1996). What Do Stock Splits Really Signal? Journal of Financial and Quantitative Analysis, 31(3), 357-377.

Jegadeesh N. (2000). Long-Term Performance of Seasoned Equity Offerings: Benchmark Errors and Biases in Expectations, Financial Management, 29(3), 5-30. 
Jensen M.C. (1986). Agency Costs of Free Cash Flow, Corporate Finance, and Takeovers. The American Economic Review, 76(2), 323-329.

Jensen M.C. (1988). Takeovers: their Causes and Consequences. Journal of Economic Perspectives, 2(1), 21-48.

Jensen M.C., \& Fama E.F. (1983). Separation of Ownership and Control. The Journal of Law and Economics, 26(2), 301-325.

Jensen M.C., \& Meckling W.H. (1976). Theory of the Firm: Managerial Behaviour, Agency Costs and Ownership Structure. Journal of Financial Economics, 3(4), 305-360.

Jensen M.C, Crutchley C.E., \& Hudson C.D. (1994). Market Reaction to Equity Offer Reasons: What Information Do Managers Reveal? Journal of Economics and Finance, 18(3), 313.

Jiao Y., \& Chemmanur T.J. (2005). Seasoned Equity Issues With 'Soft' Information: Theory and Empirical Evidence, available at https://papers.ssrn.com/sol3/papers.cfm?abstract_id=674102

John K., \& Williams J. (1985). Dividends, Dilution, and Taxes: A Signalling Equilibrium, The Journal of Finance, 40(4), 1053-1070.

Jung K., Kim Y.C., \& Stulz R.M. (1996). Timing, Investment Opportunities, Managerial Decisions, and the Security Issue Decision. Journal of Financial Economics, 42(2), 159-185.

Keeley M.C. (1989). The Stock Price Effects of Bank Holding Company Securities Issuance. Economic Review, Federal Reserve Bank of San Francisco, No 1, available at https://ideas.repec.org/a/fip/fedfer/y1989iwinp3-19.html 
Kim E.H., \& Purnanandam A.K. (2014). Seasoned Equity Offerings, Corporate Governance, and Investments, Review of Finance, 18(3), 1023-1057.

Krishnan, CNV, Ergungor O., Laux P., Singh A., \& Zebedee A. (2010). Examining Bank SEOs: Are Offers Made by Undercapitalized Banks Different? Journal of Financial Intermediation, 19(2), 207-234.

LaPorta, R., F. Lopez-de-Silanes, and A. Shleifer (1999). Corporate ownership around the world, Journal of Finance, 54 (2), 471-517.

LaPorta, R., F. Lopez-de-Silanes, and A. Shleifer (2008). The economic consequences of legal origins, Journal of Economic Literature, 46 (2), 285-322

LaPorta, R., F. Lopez-de-Silanes, A. Shleifer, and R. Vishny (1997). Legal determinants of external finance, Journal of Finance, 52 (3), 1131-1150.

LaPorta, R., F. Lopez-de-Silanes, A. Shleifer, and R. Vishny (1998). Law and finance, Journal of Political Economy, 106 (6), 1113-1155.

LaPorta, R., F. Lopez-de-Silanes, A. Shleifer, and R. Vishny (2000a). Investor protection and corporate governance, Journal of Financial Economics, 58 (1), 1-25.

LaPorta, R., F. Lopez-de-Silanes, A. Shleifer, and R. Vishny (2000b). Agency problems and dividend policies around the world, Journal of Finance, 55 (1), 1-33.

Labie M., \& Périlleux A. (2008). Corporate Governance in Microfinance: Credit Unions. Université Libre de Bruxelles, Solvay Business School, Centre Emile Bernheim (CEB) Working Papers, 8(3), 1-16.

Lakonishok J., \& Vermaelen T. (1986). Tax-induced Trading Around Ex-Dividend Days. Journal of Financial Economics, 16(3), 287-319. 
Lamoureux C.G., \& Poon P. (1987). The Market Reaction to Stock Splits. Journal of Finance, 42(5), 1347-1370.

Lease R., Netter J., \& Poulsen A. (1990). Consolidating Corporate Control: Dual-class

Recapitalizations versus leveraged buyout. Journal of Financial Economics, 27, 557-580.

Lee I. (1997). Do Firms Knowingly Sell Overvalued Equity? The Journal of Finance, 52(4), $1439-1466$.

Leland H.E., \& Pyle D.H. (1977). Informational Asymmetries, Financial Structure, and Financial Intermediation, The Journal of Finance, 32(2), 371-387.

Lemmon M.L., \& Zender J.F. (2004). Debt Capacity and Tests of Capital Structure Theories, Journal of Financial and Quantitative Analysis, 45(5), 1161-1187.

Lie E. (2002). Do Firms Undertake Self-Tender Offers to Optimize Capital Structure? The Journal of Business, 75(4), 609-639.

Loderer C., Cooney J.W., \& van Drunen L.D. (1991). The Price Elasticity of Demand for Common Stock, The Journal of Finance, 46(2), 621-651.

Loncarski I., ter Horst J., \& Veld C. (2006). Why Do Companies Issue Convertible Bonds? A Review of Theory and Empirical Evidence, in 'Advances in Corporate Finance and Asset Pricing', L.D.R. Renneboog (ed.), Amsterdam, Elsevier.

Loughran T., \& Ritter J.R. (1997). The Operating Performance of Firms Conducting Seasoned Equity Offerings. The Journal of Finance, 52(5), 1823-150.

Malmendier U., \& Tate G. (2005). CEO Overconfidence and Corporate Investment, The Journal of Finance, 60(6), 2661-2700. 
Manne H.G. (1965). Mergers and the Market for Corporate Control, Journal of Political Economy, 73(2), 110-120.

Marisetty V.B., Marsden A., \& Veeraraghavan M. (2007). Price Reaction to Right Issues in the Indian Capital Market. Pacific-Basin Finance Journal, 16(3), 316-340.

Massa M., Vermaelen T., \& Groen-Xu M. (2013). Rights Offerings, Trading, and Regulation: A global perspective. London Schools of Economics, available at http://www.lse.ac.uk/finance/people/profiles/pdfs/Xu/RightsIssues.pdf

Masulis R.W. (1987). Changes in Ownership Structure: Conversions of Mutual Savings and Loans to Stock Charter. Journal of Financial Economics, 18(1), 29-59.

Masulis R.W., \& Korwar A.N. (1986). Seasoned Equity Offerings: An Empirical Investigation. Journal of Financial Economics, 15(1-2), 91-118.

Merton R.C. (1987). A Simple Model of Capital Market Equilibrium with Incomplete Information. The Journal of Finance, 42(3), 483-510.

Mikkelson W.H., \& Partch M.M. (1986). Valuation Effects of Security Offerings and the Issuance Process. Journal of Financial Economics, 15(1-2), 31-60.

Mitchell M.L., \& Stafford E. (2000). Managerial Decisions and Long-Term Stock Price Performance, The Journal of Business, 73(3), 287-329.

Miller M.H., \& Rock K. (1985). Dividend Policy Under Asymmetric Information. Journal of Finance, 40(4), 1031-1051.

Mola S., \& Loughran T. (2004). Discounting and Clustering in Seasoned Equity Offering Prices, Journal of Financial and Quantitative Analysis, 39(1), 1-23. 
Moore J.H., \& Kraatz M.S. (2011). Governance Form and Organizational Adaptation:

Lessons from the Savings and Loan Industry in the 1980s. Organization Science, 22(4), 850 868.

Mosetti U., \& Santella P. (2000). Corporate Governance nelle Banche di Credito

Cooperativo, Università di Siena, Facoltà di Economia, available at http://www.econ-

pol.unisi.it/scdbanc/pubbl/bcc.pdf

Morck R., Shleifer A., \& Vishny R.W. (1990). Do Managerial Objective Drive Bad Acquisitions? The Journal of Finance, 45(1), 31-48.

Myers S.C., \& Majluf N.S. (1984). Corporate Financing and Investment Decisions When Firms Have Information That Investors Do Not Have. Journal of Financial Economics, 13(2), $187-221$.

OECD (1999). OECD Principle of Corporate Governance, available at https://www.oecd.org/officialdocuments/publicdisplaydocumentpdf/?cote=C/MIN(99)6\&doc Language $=$ En .

OECD (2004). OECD Principle of Corporate Governance, available at http://www.oecd.org/corporate/ca/corporategovernanceprinciples/31557724.pdf

Pajuste A. (2005). Determinants and Consequences of the Unification of Dual-Class Shares. European Central Bank, Working Paper, N. 465, available at https://www.ecb.europa.eu/pub/pdf/scpwps/ecbwp465.pdf?2a436e67ce16b853494adab3efb2 $55 \mathrm{~d} 7$. 
Palomo Zurdo J.R., \& Sanchis Palacio R.J. (2008). Un Análisis del Crédito Cooperativo en España: Situación Actual, Expansión Territorial y Proyección Estratégica. Estudios de Economía Aplicada, 26, 89-132.

Petersen M.A., \& Rajan R.G. (1994). The Benefits of Lending Relationships: Evidence from Small Business Data. The Journal of Finance, 49(1), 3-37.

Pittaluga G.B., Morelli P., \& Seghezza E. (2002). Fondamenti Teorici della Corporate Governante e Comportamenti delle Banche Popolari, in 'Le Banche Popolari nel localismo dell'economia italiana'. Working Paper n. 2/2005, Associazione Nazionale fra le Banche Popolari.

Roskelley K., \& Gokkaya S. (2011). Asymmetric Revisions to Primary and Secondary Shares in Seasoned Equity Offerings, available at http://ssrn.com/abstract=1764042

Scharfstein D. (1988). The Disciplinary Role of Takeover. Review of Economic Studies, 55(2), 185-199.

Spamann H. (2010). The ‘Anti-Director Index’ Revised. Review of Financial Studies, 23(2), $467-486$

Wall L.D., \& Peterson P.P. (1991). Valuation Effect of New Capital Issues by Large Bank Holding Companies. Journal of Financial Services Research, 5(1), 77-87.

Welch I. (1989). Seasoned Offerings, Imitation Costs, and the Underpricing of Initial Public Offerings. The Journal of Finance, 44(2), 421-449

White H. (1980). A Heteroskedasticity-Consistent Covariance Matrix Estimator and a Direct Test for Heteroskedasticity. Econometrica, 48(4), 817-838. 
Zingales L. (1994). The Value of the Voting Right: A Study of the Milan Stock Exchange Experience. Review of Financial Studies, 7(1), 125-148. 


\section{Appendix}

Table A1

Main features of Italian Cooperative Banks before the Reform of PBs (DL 24/1/2015, n. 3, and Law 24/3/2015, n. 33) and of BCCs (DL 14/2/2016, n. 18 and Law 8/4/16 n. 49).

\begin{tabular}{|c|c|c|}
\hline & Banche Popolari (PBs) & Banche di Credito Cooperativo (BCCs) \\
\hline $\begin{array}{l}\text { Mutualistic } \\
\text { features }\end{array}$ & No & $\begin{array}{l}\text { According to the Banking law (Art. 35), they shall } \\
\text { grant credit primarily to their members. Credit } \\
\text { operations with members need to account for at least } \\
\text { half of the risk weighted assets of the bank. For } \\
\text { stability reasons Bank of Italy (BoI) can establish } \\
\text { exceptions. }\end{array}$ \\
\hline $\begin{array}{l}\text { Regional limits to } \\
\text { expansion }\end{array}$ & No & $\begin{array}{l}\text { The Banking Law (Art. 35) establishes that the } \\
\text { bylaws shall contain provisions governing their } \\
\text { geographical operating limits, established based on } \\
\text { the criteria laid down by the BoI. According to these } \\
\text { criteria, banks can expand to an adjacent region if } \\
\text { they have more than } 200 \text { members in that region. }\end{array}$ \\
\hline $\begin{array}{l}\text { Tradability of } \\
\text { shares }\end{array}$ & Yes & No \\
\hline Voting rules & One head-one vote (Banking Law, Art. 30). & One head-one vote (Banking Law, Art. 34). \\
\hline $\begin{array}{l}\text { Limits to } \\
\text { shareholder } \\
\text { participations }\end{array}$ & $\begin{array}{l}0.5 \text { percent of capital for individuals. Undertaking } \\
\text { of collective investment in transferable securities } \\
\text { may hold percentage of capital up to the limit } \\
\text { provided for in their bylaws (Banking Law, art. } \\
\text { 30), which cannot exceed } 10 \text { percent (BoI } \\
\text { regulations) }\end{array}$ & $\begin{array}{l}\text { Euro 50,000 per member (Banking Law, Art. 33). No } \\
\text { distinction between individuals or legal entities. }\end{array}$ \\
\hline $\begin{array}{l}\text { Limits to } \\
\text { collection of } \\
\text { proxies }\end{array}$ & $\begin{array}{l}\text { The Civil Code requires the maximum number of } \\
\text { proxy votes to be } 10 \text { (Art. 2539). }\end{array}$ & $\begin{array}{l}\text { The Civil Code requires the maximum number of } \\
\text { proxy votes to be } 10 \text { (Art. 2539); the BCCs } \\
\text { association recommends a maximum of three proxy } \\
\text { votes for each member. }\end{array}$ \\
\hline $\begin{array}{l}\text { Membership } \\
\text { requires board } \\
\text { approval }\end{array}$ & $\begin{array}{l}\text { Yes. Non-members may still hold shares but only } \\
\text { enjoy property rights and cannot vote or exert other } \\
\text { member rights (Banking Law, Art. 30). }\end{array}$ & Yes \\
\hline Profit allocation & $\begin{array}{l}\text { PBs must allocate at least } 10 \text { percent of net profits } \\
\text { to the legal reserve. Profits not allocated to the } \\
\text { legal reserve, other reserves, as per bylaws or } \\
\text { distributed among members must be distributed to } \\
\text { charity (Banking Law, Art. 32). }\end{array}$ & $\begin{array}{l}\text { The Banking Law (Art. 37) requires BCCs to allocate } \\
\text { at least } 70 \text { percent of annual net profit to reserves. In } \\
\text { addition, a total of } 3 \text { percent of the net profit shall be } \\
\text { paid into a special mutual aid fund (Fondo Sviluppo } \\
\text { SpA, set up by Federcasse and Conf cooperative) for } \\
\text { the promotion and development of cooperation. }\end{array}$ \\
\hline $\begin{array}{l}\text { Conversion to } \\
\text { joint stock } \\
\text { company }\end{array}$ & $\begin{array}{l}\text { They can convert into joint stock companies if the } \\
\text { members decide so. For stability reasons BoI can } \\
\text { authorize conversion or merger with another entity } \\
\text { resulting in conversion to public company. In this } \\
\text { case, the smaller quorum required by the bylaws } \\
\text { for any of these actions shall apply (Banking Law, } \\
\text { Art. 31). }\end{array}$ & $\begin{array}{l}\text { To change status, the bank must be liquidated and } \\
\text { what would be left after liquidation of a BCC should } \\
\text { also be paid into Fondo Sviluppo. BoI, in the interest } \\
\text { of creditors and where considerations of stability are } \\
\text { involved, shall authorize mergers between banche di } \\
\text { credito cooperative and banks of different nature, } \\
\text { which result in the formation of banche popolari or } \\
\text { banks having the form of joint stock company } \\
\text { (Banking Law, Art. } 36 \text { ). }\end{array}$ \\
\hline
\end{tabular}


Table A2

Variable description.

\begin{tabular}{|c|c|}
\hline Variable & Description \\
\hline dependent variables & \\
\hline $\begin{array}{l}\text { CAR }(-3,+3) \text { sector adjusted } \\
\text { CAR }(-3,+3) \text { market adjusted }\end{array}$ & $\begin{array}{l}\text { Sector adjusted CAR from } \mathrm{t}=-3 \text { to } \mathrm{t}=3 \text {. } \\
\text { Market model adjusted CAR from } \mathrm{t}=-3 \text { to } \mathrm{t}=3 \text {. }\end{array}$ \\
\hline independent variables & \\
\hline $\begin{array}{l}\text { explanatory variable } \\
\text { CB }\end{array}$ & Dummy variable equal to 1 if the bank is a co-operative bank. \\
\hline $\begin{array}{l}\text { control variables (rights issue) } \\
\text { upon payment } \\
\text { shares only } \\
\text { aiaf factor } \\
\text { relative issue size } \\
\text { issuing-to-market price } \\
\text { overprice }\end{array}$ & $\begin{array}{l}\text { Dummy variable equal to } 1 \text { if the rights issue is upon payment } \\
\text { Dummy variable equal to } 1 \text { if the announcement concerns a pure stock issue (no convertible } \\
\text { bonds or warrants are issued at the same time). } \\
\text { Price rectifier factor (source: AIAF, Italian Association of Financial Analysts). } \\
\text { Money raised with the issue (source: Borsa Italiana Bitstat and Sole } 24 \text { Ore) over the issuing } \\
\text { bank's market value as of December } 31 \text { st preceding the announcement day. } \\
\text { Share issuing price, } P_{I} \text {, over share market price, } P_{M} \text {, in } t=-1, P_{I} / P_{M} \text { (source: Datastream*). } \\
\left(P_{I}-P_{V}\right) /\left(P_{M}-P_{V}\right) \text {, where } P_{V} \text { is the par value of the share as reported in the bank's legal } \\
\text { charter. }\end{array}$ \\
\hline $\begin{array}{l}\text { control variables (bank) } \\
\text { beta } \\
\text { price-to-book value } \\
\text { roe } \\
\text { market capitalization }(\log )\end{array}$ & $\begin{array}{l}\text { Beta of the issuing bank (calculated using daily returns from }-130 \text { to }-31 \text { with respect to the } \\
\text { announcement day). } \\
\text { Price-to-book-value, estimated as the average of daily values from }-55 \text { to }-31 \text { with respect to } \\
\text { the announcement day (source: Datastream*). The price-to-book value is calculated as the } \\
\text { ratio of the market and book value of equity. } \\
\text { Return on equity of the issuing bank in the announcement year (source: Datastream*). } \\
\text { Natural logarithm of the issuing bank's market value as of December } 31 \text { st preceding the } \\
\text { announcement day (source: Mediobanca Indici e Dati). Values are corrected for inflation. }\end{array}$ \\
\hline $\begin{array}{l}\text { control variables (market) } \\
\text { upward market trend } \\
\text { post } 2007\end{array}$ & $\begin{array}{l}\text { Dummy variable equal to } 1 \text { if the bank index (MILAN COMIT BANKING) return in the six } \\
\text { months before the announcement day is positive. } \\
\text { Dummy variable equal to } 1 \text { if the announcement took place after } 2007 \text {. }\end{array}$ \\
\hline
\end{tabular}

* Missing values have been filled in relying on other sources. 
Table 1

Sample composition

\begin{tabular}{|c|c|c|c|c|c|}
\hline \multirow[b]{2}{*}{ Rights issues } & \multicolumn{2}{|c|}{ PB } & \multicolumn{2}{|c|}{ JSB } & \multirow{2}{*}{$\begin{array}{c}\text { Total } \\
\#\end{array}$} \\
\hline & \# & $\%$ & $\#$ & $\%$ & \\
\hline All & 66 & 57.89 & 48 & 42.11 & 114 \\
\hline Upon payment & 47 & 56.63 & 36 & 43.37 & 83 \\
\hline Partially upon payment and for free & 19 & 61.29 & 12 & 38.71 & 31 \\
\hline Shares only or shares and other securities & 41 & 47.67 & 45 & 52.33 & 86 \\
\hline Shares (only) & 29 & 43.94 & 37 & 56.06 & 66 \\
\hline Other securities (only) & 25 & 89.29 & 3 & 10.71 & 28 \\
\hline Shares only or shares and other securities upon payment & 22 & 40.00 & 33 & 60.00 & 55 \\
\hline Shares (only) upon payment & 16 & 37.21 & 27 & 62.79 & 43 \\
\hline
\end{tabular}

Table 1 describes our sample of 114 rights issues distinguishing between rights issues pertaining fifteen PBs and twenty-five JSBs. Observations are grouped by the type of rights issue, kind of issued securities and a combination thereof. 
Table 2

ARs and CARs

Panel A - Sector adjusted abnormal returns

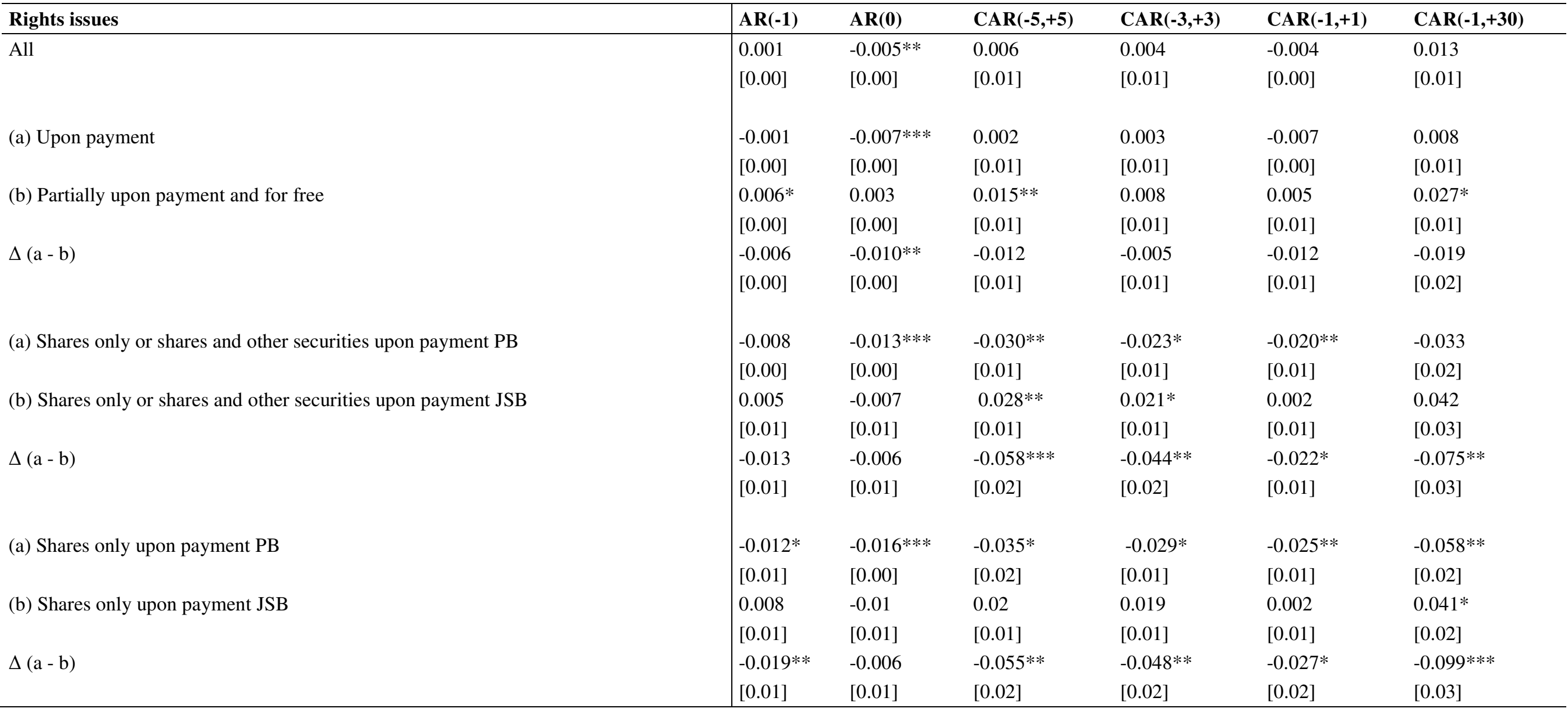




\begin{tabular}{|c|c|c|c|c|c|c|}
\hline \multicolumn{7}{|l|}{ Panel B - Market adjusted abnormal returns } \\
\hline Rights issues & AR(-1) & $\mathbf{A R}(\mathbf{0})$ & CAR(-5,+5) & CAR $(-3,+3)$ & CAR(-1,+1) & CAR(-1,+30) \\
\hline \multirow[t]{2}{*}{ All } & 0.001 & $-0.004 * *$ & 0.006 & 0.005 & -0.003 & 0.016 \\
\hline & {$[0.00]$} & {$[0.00]$} & {$[0.01]$} & {$[0.01]$} & {$[0.00]$} & {$[0.01]$} \\
\hline \multirow[t]{2}{*}{ (a) Upon payment } & 0.000 & $-0.006^{* *}$ & 0.007 & 0.005 & -0.004 & 0.022 \\
\hline & {$[0.00]$} & {$[0.00]$} & {$[0.01]$} & {$[0.01]$} & {$[0.00]$} & {$[0.01]$} \\
\hline (b) Partially upon payment and for free & {$[0.00]$} & {$[0.00]$} & [0.01] & [0.01] & {$[0.01]$} & [0.02] \\
\hline \multirow[t]{2}{*}{$\Delta(\mathrm{a}-\mathrm{b})$} & -0.004 & -0.007 & 0.005 & 0.001 & -0.005 & 0.022 \\
\hline & {$[0.00]$} & {$[0.00]$} & [0.01] & [0.01] & {$[0.01]$} & [0.02] \\
\hline \multirow[t]{2}{*}{ (a) Shares only or shares and other securities upon payment PB } & $-0.007 *$ & $-0.015 * * *$ & $-0.028 *$ & $-0.028 * *$ & $-0.024 * * *$ & -0.034 \\
\hline & {$[0.00]$} & {$[0.00]$} & {$[0.01]$} & {$[0.01]$} & {$[0.01]$} & {$[0.02]$} \\
\hline (b) Shares only or shares and other securities upon payment JSB & 0.004 & -0.005 & $0.033 * *$ & $0.032 * *$ & 0.007 & $0.059 * *$ \\
\hline \multirow[t]{2}{*}{$\Delta(\mathrm{a}-\mathrm{b})$} & $-0.011 *$ & -0.010 & $-0.061 * * *$ & $-0.060 * * *$ & $-0.030 * *$ & $-0.092 * *$ \\
\hline & {$[0.01]$} & {$[0.01]$} & {$[0.02]$} & {$[0.02]$} & {$[0.01]$} & {$[0.04]$} \\
\hline \multirow[t]{2}{*}{ (a) Shares only upon payment PB } & $-0.009 * *$ & $-0.018 * * *$ & $-0.032 *$ & $-0.033^{*}$ & $-0.026^{* * *}$ & -0.042 \\
\hline & {$[0.00]$} & {$[0.00]$} & {$[0.02]$} & {$[0.02]$} & [0.01] & {$[0.03]$} \\
\hline \multirow[t]{2}{*}{ (b) Shares only upon payment JSB } & 0.007 & -0.007 & $0.027 * *$ & $0.032 * *$ & 0.008 & $0.061 * *$ \\
\hline & {$[0.01]$} & {$[0.01]$} & {$[0.01]$} & {$[0.02]$} & {$[0.01]$} & {$[0.03]$} \\
\hline \multirow[t]{2}{*}{$\Delta(\mathrm{a}-\mathrm{b})$} & $-0.016^{* *}$ & -0.010 & $-0.059 * * *$ & $-0.065 * * *$ & $-0.035 * *$ & $-0.103 * *$ \\
\hline & {$[0.01]$} & {$[0.01]$} & {$[0.02]$} & {$[0.02]$} & {$[0.01]$} & {$[0.04]$} \\
\hline
\end{tabular}

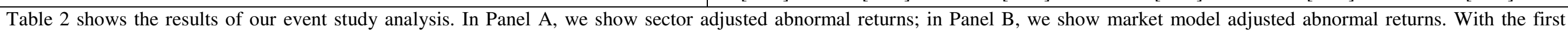

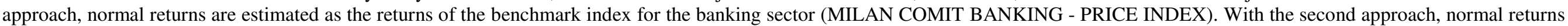

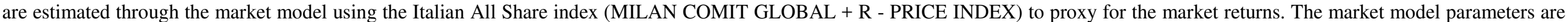

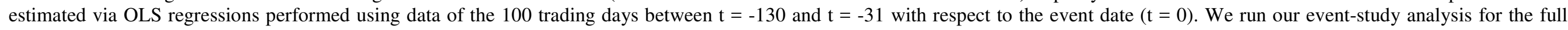

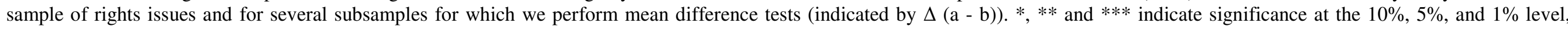
respectively. 
Table 3

\begin{tabular}{|c|c|c|c|c|c|c|c|c|c|c|}
\hline Group & \multicolumn{3}{|c|}{ All observations } & \multicolumn{3}{|c|}{ PB } & \multicolumn{3}{|c|}{ JSB } & \multirow{2}{*}{$\begin{array}{c}\Delta(\mathbf{a}-\mathbf{b}) \\
\text { Diff } \\
\end{array}$} \\
\hline Variable & Obs & Median & Mean & Obs & Median & Mean (a) & Obs & Median & Mean (b) & \\
\hline PB & 114 & & 0.579 & & & & & & & \\
\hline upon payment & 114 & & 0.728 & 66 & & 0.712 & 48 & & 0.750 & -0.038 \\
\hline shares only & 114 & & 0.579 & 66 & & 0.439 & 48 & & 0.771 & $-0.331 * * *$ \\
\hline aiaf factor & 114 & 0.937 & 0.865 & 66 & 0.937 & 0.865 & 48 & 0.940 & 0.864 & 0.001 \\
\hline relative issue size & 114 & 0.209 & 0.327 & 66 & 0.265 & 0.300 & 48 & 0.178 & 0.365 & -0.065 \\
\hline issuing-to-market price & 83 & 0.640 & 0.669 & 41 & 0.623 & 0.633 & 42 & 0.660 & 0.704 & -0.071 \\
\hline overprice & 74 & 0.549 & 0.551 & 35 & 0.506 & 0.479 & 39 & 0.571 & 0.616 & $-0.137 * *$ \\
\hline beta & 114 & 0.542 & 0.658 & 66 & 0.427 & 0.532 & 48 & 0.683 & 0.831 & $-0.299 * * *$ \\
\hline price-to-book value & 114 & 1.051 & 1.195 & 66 & 0.914 & 0.995 & 48 & 1.426 & 1.469 & $-0.474 * * *$ \\
\hline roe & 114 & 0.064 & 0.051 & 66 & 0.056 & 0.039 & 48 & 0.079 & 0.068 & -0.030 \\
\hline market capitalization $(\log )$ & 114 & 7.095 & 7.117 & 66 & 6.926 & 6.775 & 48 & 7.798 & 7.587 & $-0.812 * * *$ \\
\hline upward market trend & 114 & & 0.632 & 66 & & 0.667 & 48 & & 0.583 & 0.083 \\
\hline post 2007 & 114 & & 0.237 & 66 & & 0.227 & 48 & & 0.250 & -0.023 \\
\hline
\end{tabular}

In Table 3, we provide mean (and median for continuous variables) values for rights issues, bank and market observable characteristics distinguishing between PBs and JSBs. Mean difference tests are reported in the last column on the right. *,** and *** indicate significance at the $10 \%, 5 \%$, and $1 \%$ level, respectively. 
Table 4

Regression analysis.

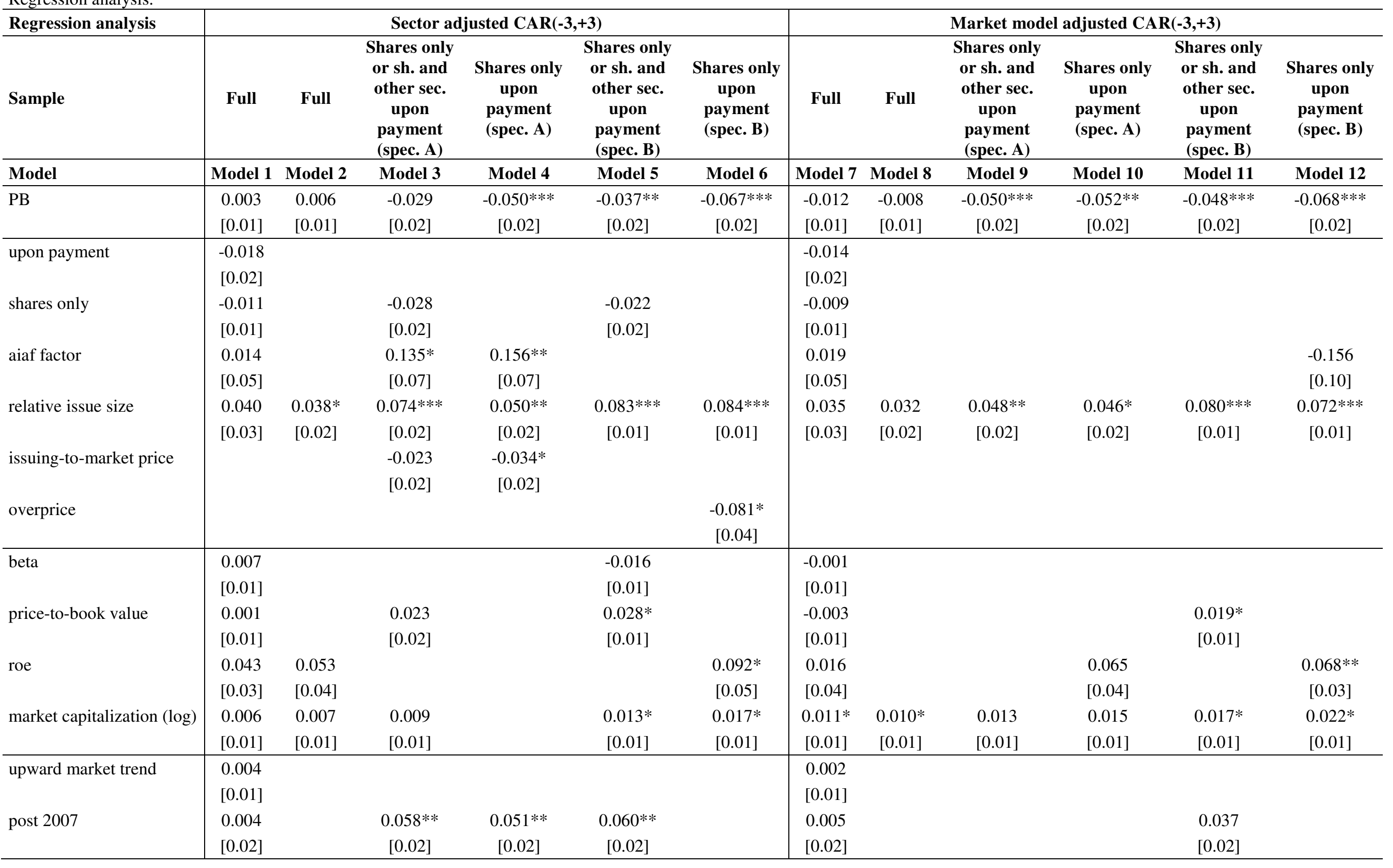




\begin{tabular}{|c|c|c|c|c|c|c|c|c|c|c|c|c|}
\hline constant & $\begin{array}{l}-0.061 \\
{[0.06]} \\
\end{array}$ & $\begin{array}{l}-0.064 \\
{[0.04]} \\
\end{array}$ & $\begin{array}{c}-0.212^{*} \\
{[0.11]} \\
\end{array}$ & $\begin{array}{c}-0.133 * \\
{[0.08]} \\
\end{array}$ & $\begin{array}{c}-0.134 * \\
{[0.07]} \\
\end{array}$ & $\begin{array}{l}-0.083 \\
{[0.07]} \\
\end{array}$ & $\begin{array}{r}-0.080 \\
{[0.07]} \\
\end{array}$ & $\begin{array}{c}-0.075^{*} \\
{[0.04]} \\
\end{array}$ & $\begin{array}{l}-0.092 \\
{[0.06]} \\
\end{array}$ & $\begin{array}{l}-0.108 \\
{[0.08]}\end{array}$ & $\begin{array}{c}-0.164 * * \\
{[0.07]} \\
\end{array}$ & $\begin{array}{l}-0.021 \\
{[0.13]}\end{array}$ \\
\hline R-squared & 0.117 & 0.099 & 0.404 & 0.341 & 0.571 & 0.605 & 0.123 & 0.109 & 0.298 & 0.291 & 0.497 & 0.518 \\
\hline Number of Observations & 114 & 114 & 55 & 43 & 47 & 35 & 114 & 114 & 55 & 43 & 47 & 35 \\
\hline
\end{tabular}

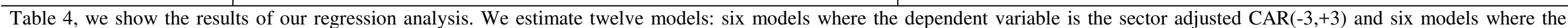

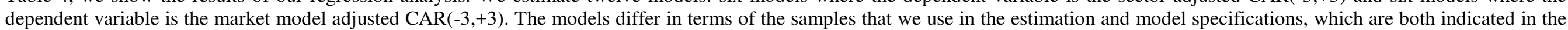

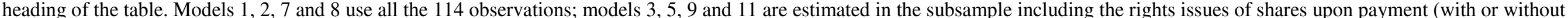

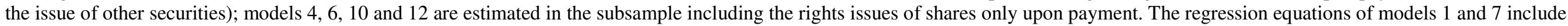

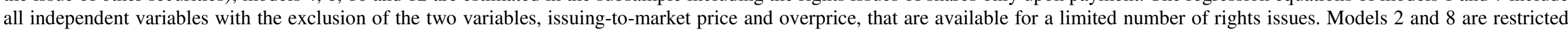

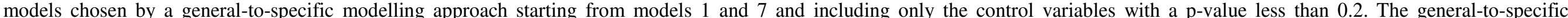

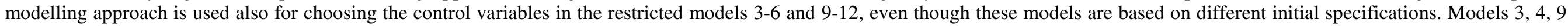

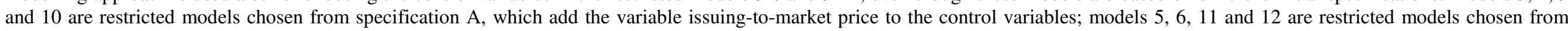

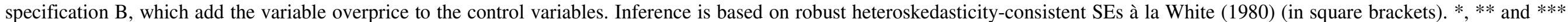
indicate significance at the $10 \%, 5 \%$, and $1 \%$ level, respectively. 
Table 5

Nearest-neighbour matching

\begin{tabular}{|c|c|c|c|c|c|c|c|c|c|c|}
\hline \multirow[b]{2}{*}{$\begin{array}{l}\text { Nearest-neighbour matching } \\
\text { Sample }\end{array}$} & \multicolumn{5}{|c|}{ Sector adjusted CAR $(-3,+3)$} & \multicolumn{5}{|c|}{ Market model adjusted CAR( $(-3,+3)$} \\
\hline & Full & $\begin{array}{c}\text { Shares } \\
\text { only or } \\
\text { shares } \\
\text { and } \\
\text { other } \\
\text { securities } \\
\text { upon } \\
\text { payment } \\
\text { (spec. A) }\end{array}$ & $\begin{array}{l}\text { Shares } \\
\text { only upon } \\
\text { payment } \\
\text { (spec. A) }\end{array}$ & $\begin{array}{c}\text { Shares only } \\
\text { or shares and } \\
\text { other } \\
\text { securities } \\
\text { upon } \\
\text { payment } \\
\text { (spec. B) } \\
\end{array}$ & $\begin{array}{c}\text { Shares only } \\
\text { upon } \\
\text { payment } \\
\text { (spec. B) }\end{array}$ & Full & $\begin{array}{c}\text { Shares only } \\
\text { or shares and } \\
\text { other } \\
\text { securities } \\
\text { upon payment } \\
\text { (spec. } \text { A) }\end{array}$ & $\begin{array}{c}\text { Shares only } \\
\text { upon } \\
\text { payment } \\
\text { (spec. A) }\end{array}$ & $\begin{array}{l}\text { Shares only or } \\
\text { shares and } \\
\text { other securities } \\
\text { upon payment } \\
\text { (spec. B) }\end{array}$ & $\begin{array}{c}\text { Shares } \\
\text { only upon } \\
\text { payment } \\
\text { (spec. B) }\end{array}$ \\
\hline Model & Model 13 & Model 14 & Model 15 & Model 16 & Model 17 & Model 18 & Model 19 & Model 20 & Model 21 & Model 22 \\
\hline PB & $\begin{array}{l}-0.012 \\
{[0.01]}\end{array}$ & $\begin{array}{l}-0.030 \\
{[0.02]}\end{array}$ & $\begin{array}{c}-0.055^{* *} \\
{[0.02]}\end{array}$ & $\begin{array}{c}-0.079 * * * \\
{[0.02]}\end{array}$ & $\begin{array}{c}-0.108 * * * \\
{[0.03]}\end{array}$ & $\begin{array}{c}-0.031 * * \\
{[0.01]}\end{array}$ & $\begin{array}{c}-0.068 * * * \\
{[0.02]}\end{array}$ & $\begin{array}{c}-0.088 * * * \\
{[0.03]}\end{array}$ & $\begin{array}{c}-0.091 * * * \\
{[0.02]}\end{array}$ & $\begin{array}{l}-0.052 \\
{[0.07]}\end{array}$ \\
\hline Number of Observations & 114 & 55 & 43 & 47 & 35 & 114 & 55 & 43 & 47 & 35 \\
\hline
\end{tabular}

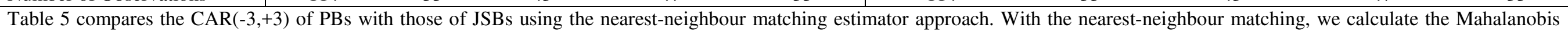

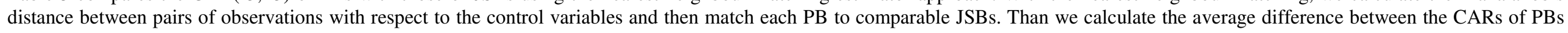
and matched JSBs. $* * *$ and $* * *$ indicate significance at the $10 \%, 5 \%$, and $1 \%$ level, respectively.

\section{Table 6}

Propensity-score matching

\begin{tabular}{|c|c|c|c|c|c|c|c|c|c|c|}
\hline \multirow[t]{2}{*}{ Propensity-score matching } & \multicolumn{5}{|c|}{ Sector adjusted CAR( $(-3,+3)$} & \multicolumn{5}{|c|}{ Market model adjusted CAR(-3,+3) } \\
\hline & Full & $\begin{array}{l}\text { Shares only or } \\
\text { shares and } \\
\text { other securities } \\
\text { upon payment } \\
\text { (spec. } A \text { ) }\end{array}$ & $\begin{array}{c}\text { Shares only } \\
\text { upon payment } \\
\text { (spec. A) }\end{array}$ & $\begin{array}{c}\text { Shares only or } \\
\text { shares and other } \\
\text { securities upon } \\
\text { payment (spec. } \\
\text { B) }\end{array}$ & $\begin{array}{l}\text { Shares only upon } \\
\text { payment (spec. B) }\end{array}$ & Full & $\begin{array}{c}\text { Shares } \\
\text { only or } \\
\text { shares } \\
\text { and } \\
\text { other } \\
\text { securities } \\
\text { upon } \\
\text { payment } \\
\text { (spec. A) } \\
\end{array}$ & $\begin{array}{c}\text { Shares } \\
\text { only } \\
\text { upon } \\
\text { payment } \\
\text { (spec. A) }\end{array}$ & $\begin{array}{c}\text { Shares } \\
\text { only or } \\
\text { shares } \\
\text { and } \\
\text { other } \\
\text { securities } \\
\text { upon } \\
\text { payment } \\
\text { (spec. B) } \\
\end{array}$ & $\begin{array}{c}\text { Shares } \\
\text { only } \\
\text { upon } \\
\text { payment } \\
\text { (spec. B) }\end{array}$ \\
\hline Model & Model 13 & Model 14 & Model 15 & Model 16 & Model 17 & Model 18 & Model 19 & Model 20 & Model 21 & Model 22 \\
\hline $\mathrm{PB}$ & $\begin{array}{l}-0.005 \\
{[0.03]}\end{array}$ & $\begin{array}{c}-0.041 * * * \\
{[0.02]}\end{array}$ & $\begin{array}{l}-0.031 \\
{[0.03]}\end{array}$ & $\begin{array}{c}-0.092 * * * \\
{[0.02]}\end{array}$ & $\begin{array}{c}-0.050 * * * \\
{[0.02]}\end{array}$ & $\begin{array}{l}-0.023 \\
{[0.03]}\end{array}$ & $\begin{array}{c}-0.057 * * * \\
{[0.02]}\end{array}$ & $\begin{array}{c}-0.062 * * \\
{[0.03]}\end{array}$ & $\begin{array}{c}-0.100 * * * \\
{[0.01]}\end{array}$ & $\begin{array}{c}-0.069 * * * \\
{[0.02]}\end{array}$ \\
\hline Number of Observations & 114 & 55 & 43 & 47 & 35 & 114 & 55 & 43 & 47 & 35 \\
\hline
\end{tabular}

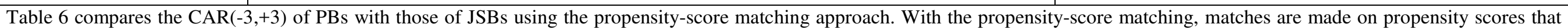

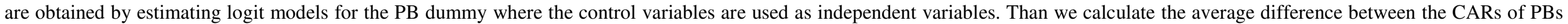
and matched JSBs. $*, * *$ and $* * *$ indicate significance at the $10 \%, 5 \%$, and $1 \%$ level, respectively. 